\title{
Repealing the Çatalhöyük extractive metallurgy: The green, the fire and the 'slag'
}

\section{Miljana Radivojević ${ }^{*}$, Thilo Rehren ${ }^{2 *}$, Shahina Farid ${ }^{2}$, Ernst Pernicka ${ }^{3} \&$ Duygu Camurcuoğlu ${ }^{4}$}

\footnotetext{
${ }^{1}$ McDonald Institute for Archaeological Research, University of Cambridge, Cambridge, UK; mr664@cam.ac.uk

${ }^{2}$ UCL Institute of Archaeology, London, UK; th.rehren@ucl.ac.uk, and College of Humanities and Social Sciences, HBKU, Doha, Qatar

${ }^{3}$ Curt Engelhorn Zentrum Archaeometrie, Mannheim, Germany

${ }^{4}$ Department of Conservation, The British Museum, London, UK
}

*corresponding authors 


\begin{abstract}
The scholarly quest for the origins of metallurgy has focused on a broad region from the Balkans to Central Asia, with different scholars advocating for a single origin and multiple origins, respectively. One particular find has been controversially discussed as the potentially earliest known example of copper smelting in western Eurasia, a copper 'slag' piece from the Late Neolithic to Chalcolithic site of Çatalhöyük in central Turkey. Here we present a new assessment of metal making at Çatalhöyük based on the re-analysis of minerals, mineral artefacts and hightemperature materials excavated in the 1960s by J. Mellaart and first analysed by Neuninger, Pittioni and Siegl in 1964. This paper focuses on copper-based minerals, the alleged piece of metallurgical slag, and copper metal beads, and their contextual relationship to each other. It is based on new microstructural, compositional and isotopic analyses, and a careful re-examination of the fieldwork documentation and analytical data related to the c. 8500 years old high-temperature debris at Çatalhöyük. We re-interpret the sample identified earlier as metallurgical slag as incidentally fired green pigment, which was originally deposited in a burial and later affected by a destructive fire that also charred the bones of the interred body. We also re-confirm the contemporary metal beads as made from native metal. Our results provide a new and conclusive explanation of the previously contentious find, and reposition Çatalhöyük in a new narrative of the multiple origins of metallurgy in the Old World.
\end{abstract}

\title{
Keywords: metallurgy, slag, copper minerals, pigments, Çatalhöyük, Anatolia
}




\section{Introduction}

Tracing the invention and spread of metallurgy is essential to understanding the relationship of this technology with the rise of social complexity, and ultimately, the economy of early civilisations during the transition from the Neolithic to the Metal Ages. The scholarly quest for the origins of metallurgy has focused on a broad region spanning the Balkans and Central Asia via Iran, known for the early use of metals. The site of Çatalhöyük, situated in the geographic centre of this broad region, represents a milestone in our understanding of past societies in Anatolia from as early as c. $7400 \mathrm{cal}$ BC. The outstanding architectural and material legacy of this settlement has been attracting scholarly attention ever since its discovery, making it one of the best-studied prehistoric archaeological sites globally ${ }^{1}$, with an exceptional number of specialists involved in building hypotheses on the evolution of prehistoric communities in this part of the world (Mickel, 2016).

Metallurgical activities at Çatalhöyük have long stimulated scholarly debates due to an unusually early date for a find that appeared to contain features of a metallurgical 'slag', set at c. 6500 cal BC (Neuninger et al., 1964; Mellaart, 1964; Cessford, 2005). This was based on analytical work conducted in the 1960s that identified this alleged evidence for copper smelting in an assemblage of archaeometallurgical materials dated around the mid7th millennium cal BC. However, these materials have never been fully assessed within their archaeological and technological context. The argument that the Neolithic Çatalhöyük communities were possibly smelting metal has, since then, been discussed controversially in the literature, from ardent support (Hauptmann et al., 1993; Hauptmann, 2000) to plain acceptance (Strahm, 1984) and more cautious reception (Muhly, 1989; Pernicka, 1990; Craddock, 2001; Roberts et al., 2009; Birch et al., 2013) to open scepticism (Tylecote, 1976; Radivojević et al., 2010). Against such a backdrop, a full re-analysis of the original metallurgical 'slag' from Çatalhöyük was the only way to resolve this enigma.

Major progress has been made recently in our understanding of the beginnings of metallurgy in Eurasia, pushing the boundaries of what is known about the emergence of metal extraction, chronologically and spatially (e.g. Bourgarit, 2007; Radivojević, 2007; 2012; Radivojević et al., 2010; Radivojević et al., 2013; Murillo-Barroso and Montero-Ruíz, 2012; Leusch et al., 2014). Sensorial aspects of early technology in particular are growing in importance in these debates (for the Balkans see Radivojević and Rehren, 2016; Rehren et al., 2016). Some of these studies have revived the theory of multiple origins of metal extraction in Eurasia, as opposed to the longstanding argument for its single place of invention in the Near East (see Roberts et al., 2009). In this light, and drawing from the expertise gained from studying early Balkan metallurgy, our team revisited the Çatalhöyük metallurgical evidence. We were guided by the intention to investigate further the convergence hypothesis of metal

\footnotetext{
${ }^{1}$ Full bibliography on http://www.catalhoyuk.com/research/bibliography
} 
invention (e.g. Renfrew, 1969; Radivojević, 2015), and to clarify the initial results from analyses by Neuninger et al. (1964).

A total of 41 items from Mellaart's 'metallurgical finds' (polished blocks and glass containers with dozens of small fragments) from Çatalhöyük and Hacilar were available to us, including the material analysed by Neuninger et al. (1964) and Sperl (1990; 1991) (Fig. S1, Supplementary Materials). The results of our analyses of the key Çatalhöyük finds are presented below, as the basis for a revised hypothesis on how metallurgy developed in this Neolithic site in Anatolia, and beyond.

\subsection{Early metal use in Eurasia}

The view of early metallurgy as closely interwoven with, but distinct from stone bead manufacture has been presented elsewhere (Radivojević et al., 2010: 2784; Radivojević and Rehren, 2016); the latter going back well into the $11^{\text {th }}$ millennium cal BC. By c. $6000 \mathrm{cal} \mathrm{BC}$, the use of copper minerals and native copper had spread from Anatolia and the Levant across wide parts of Eurasia, including Syria (Golden, 2010), Transcaucasia (Kavtaradze, 1999), the Balkans (Glumac and Tringham, 1990; Radivojević and Kuzmanović-Cvetković, 2014; Radivojević, 2015), Iran (Pigott, 1999; Thornton, 2009; Helwing, 2013) and Pakistan (Kenoyer and Miller, 1999). The use of copper minerals has been strongly associated with their aesthetics, as has been observed in the use of 'greenstones' as inherently related to the rich symbolism of the green colour as a fertility charm (Bar-Yosef Mayer and Porat, 2008).

By the end of the $6^{\text {th }}$ millennium cal BC, green copper minerals were transformed into copper metal by extraction, or smelting. Pernicka (1990) showed that low trace element concentrations (particularly cobalt and nickel) in copper metal indicate the use of native copper metal, based on hundreds of analyses of both objects and (native) copper from Anatolia and the Balkans (cf. Pernicka et al., 1993; Pernicka et al., 1997). The earliest securely documented evidence for copper smelting falls at around the transition of the $6^{\text {th }}$ to the $5^{\text {th }}$ millennium cal BC in the Balkans (Radivojević et al., 2010), and probably around that time in the Near East (Dougherty and Caldwell, 1966); the latter is still debated due to uncertainty concerning the archaeological and chronological evidence (cf. Frame, 2012; Thornton, 2014).

Thus, the copper 'slag' that Neuninger et al. (1964: 100-107) reported in Level VI at Çatalhöyük (c. 6500 cal BC, (Cessford, 2005: 69-70) as a potential evidence for local smelting of copper metal stands out as unusually early, by c. 1,500 years from the earliest recorded evidence elsewhere. Neuninger et al. (1964) reported that the sample in question has a limonitic core, akin to gossan, while the structure of the outer zone reflected high temperature treatment that resulted in the formation of a slag matrix with copper dross, delafossite and metal. Many scholars supported the idea of the intentional nature of a metal-making event this sample had been argued to demonstrate. While Muhly (1989) advocated that the 'slag' sample was melting (or refining) debris, Hauptmann et al. (1993) called it 'slagged ore'. Furthermore, Pernicka (1990), although acknowledging its confusing nature, interpreted 
this sample as a testimony of continuing heat treatment of different minerals, anticipating Craddock's (2001) interpretation that it sat at 'the verge of true smelting' at the site of Çatalhöyük. Tylecote (1976), on the other hand, was more careful with accepting this sample as related to metallurgy, given its low content of iron, which would have been essential for a slag formation. Radivojević et al. (2010: 2776) have commented that the limited penetration of the outer slagged ('hot') zone into the core of the studied sample suggested a short-lived thermal impact, inconsistent with a mature process of early copper extraction. Here, we present a full analytical reassessment of this and other samples from the assemblage analysed by Neuninger, Pittioni and Sperl in the 1960s, in light of analytical advances made during the last half century.

\subsection{Introduction to the site of Çatalhöyük}

Mellaart conducted excavations at Çatalhöyük from 1961 to 1963 and in 1965 . This period proved to be a 'Golden Age' for him as he had identified a Neolithic site that was hitherto unknown in central Anatolia. He had not only pushed back the boundary of the period of early farming and the domestication of cattle and plants west of the Fertile Crescent, but he also placed Çatalhöyük on the international stage of remarkable archaeological discoveries. He courted media to great effect and employed important scientific advances of the time to enhance his findings, such as ${ }^{14} \mathrm{C}$ dating, obsidian sourcing, and indeed archaeometallurgy.

The site of Çatalhöyük comprises two mounds, the East Neolithic Mound that dates from c. 7100 to 5950 cal BC (Bayliss et al., 2015; Marciniak et al., 2015) and the West, largely Chalcolithic or Late Neolithic Mound that ends at about $5600 \mathrm{cal} \mathrm{BC}$, in a seemingly continuous occupation. The mounds formed through successively constructed houses; growing in height but also in extent as peripheral areas were expanded over. As each 'layer' of abutting buildings was exposed and excavated, Mellaart designated these neighbouring buildings into Levels that defined roughly contemporary neighbourhoods. Thus, at the top of the East mound, Level I represents the latest occupation horizon with Level XII towards the base of the mound; Level XII represents the earliest structures or middens excavated but not, necessarily, the earliest at the site. Although Mellaart distinguished between 'houses' and 'shrines' (see Supplementary Materials), excavations and research conducted under the directorship of Ian Hodder (1993 - current) reviewed these distinctions and led to a preference for a non-hierarchical classification of 'building', which will be used here.

Buildings were constructed independently on the footings of the old ones, and side-by-side. The walls of one building abutting the walls of its neighbouring building created tightly clustered buildings interspersed with open 'courtyard'/midden areas. Access into the buildings was via a roof opening. Internally, they followed a standard pattern of furnishing and arrangement but were differentiated through variances in size and detail. In general, ovens and hearths lay to the south coinciding with the roof entrance above. The western side was the usual place for storage features, and shallow platforms were arranged against other walls beneath which the dead were buried. 
Some buildings were embellished with wall art of geometric and figural paintings and moulded plaster relief sculpture. 


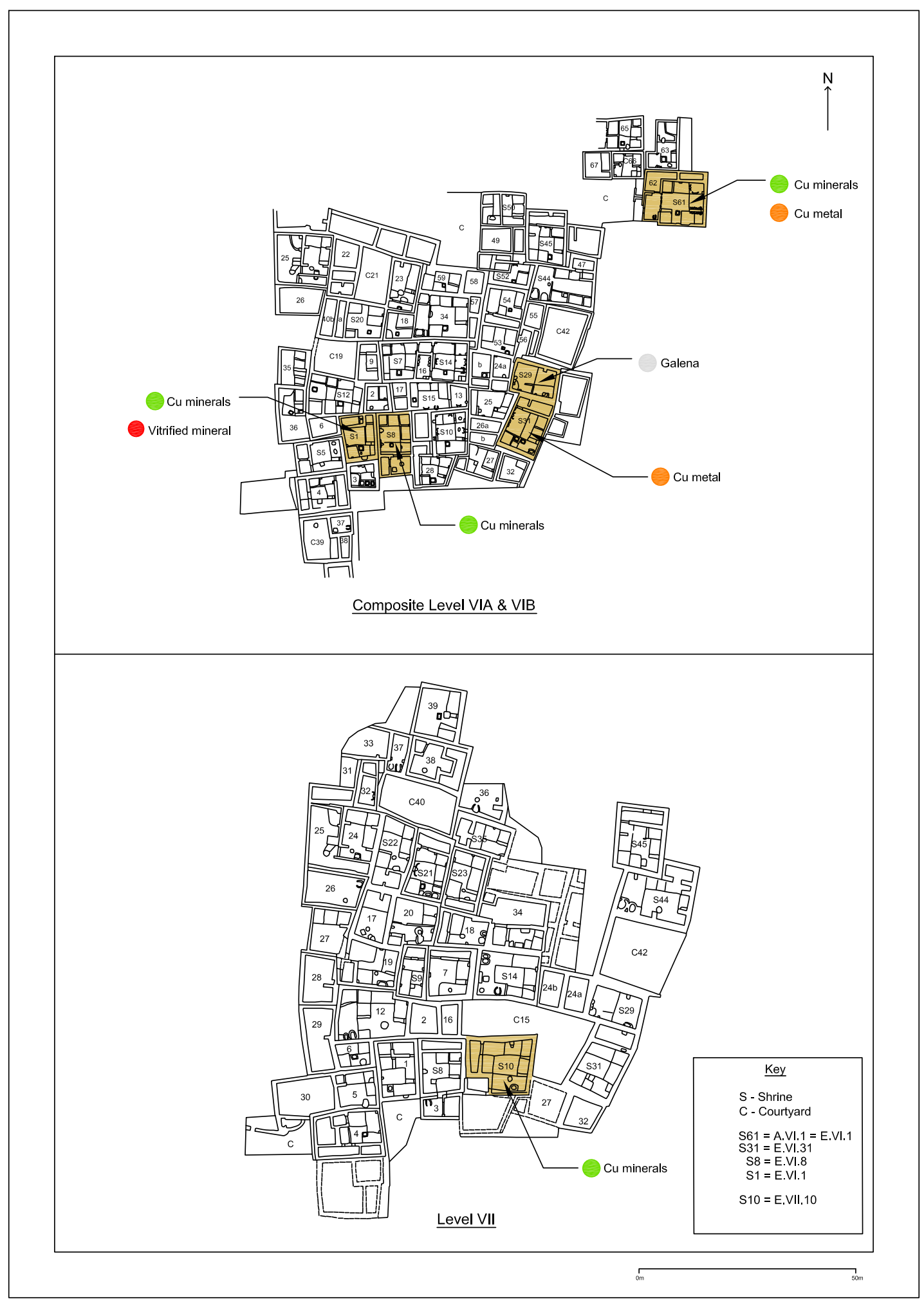

Figure 1: Floor plan for Levels VI (A\&B) and VII with indicated building contexts and nature of studied samples. 


\subsection{Mellaart and metallurgy}

It is difficult to assess Mellaart's excavation and sampling methodology as very little of the original archive survived a fire at his home in Istanbul in 1977 (J. Mellaart, pers. comm.). The available information mainly consists of the annual Anatolian Studies reports (Mellaart, 1962; 1963; 1964; 1966), his synthesis account (Mellaart, 1967) and some other published materials ${ }^{2}$. Beyond this, there is neither a comprehensive inventory of finds, nor any contextual records - that is the description of deposit type with lists of finds by deposit type or by building. Thus, the data available is very limited, despite detailed reports by artefact, which report on the material assemblage only (e.g. Bialor, 1962; Burnham, 1965; Mellaart, 1964: 73, 85, 92; Angel, 1971), rather than in conjunction with depositional events. Similarly, the 'Neolithic use of Metal' (Mellaart, 1964: 111) provides an overview of the material, the technology and the possible use of the objects; but lacking a comprehensive list of all metal finds and without the detailed description within depositional events, further interpretation is very limited. It is interesting to note, however, that whilst Mellaart was not an expert in the subject, it does, nevertheless, coincide with the report by Neuninger et al. (1964) and an article by Wertime (1964) at the end of that year, suggesting that Mellaart by this time had some specialist input. It is significant for the purpose of this paper that the renewed excavations, with ongoing field seasons from 1993 and careful sieving and flotation of excavated soil, revealed only very few further metal finds from the early layers. Most finds from the resumed excavation campaign recorded on site as metal were intrusive and of much later (Roman and Byzantine) date (Birch et al. 2013: 310). No further suspected metallurgical slag (or other metal production debris) has been identified to date.

The samples that Neuninger et al. (1964: 100-107) analysed came from six buildings only (Fig. 1, Table 1), from Levels VII and VI on the East Mound, and it is possible that some of the unprovenanced fragments, marked Level VI, could have come from the open midden areas that Mellaart called 'courtyards'. The six buildings, all defined by Mellaart as shrines (see Supplementary Materials for details on this designation), represent only 2 percent of the nearly 300 buildings recorded or excavated.

The only 'list' of metals is a published table (Mellaart, 1967: 81, Table 13) and shows a presence of metal artefacts identified as such by the excavator plotted against some shrines, together with wall paintings, plaster reliefs and materials like mirrors or cult statuettes. The table relevant to metals lists the 'Level' and 'Shrine number' in the yaxis, with types of motifs within the 'wall paintings' and 'plaster reliefs', and artefacts-types within 'burials' in the X-axis. In total, 58 'shrines' are listed spanning Levels II to IX with the presence of metal shown in 11 shrines. This table only shows a presence/absence marker and therefore gives no information on the form of the metal or any description that would inform the veracity of depositional intent. Significantly, as will be shown in the analyses below, Mellaart apparently did not distinguish minerals from metals (see Table 2). Throughout his reports, Mellaart's 'metallurgical' terminology included copper, ores, slag, lead, galena and lignite; however, none of these

\footnotetext{
${ }^{2}$ http://www.catalhoyuk.com/research/bibliography
} 
differentiations are seen in the presence / absence of 'metal' finds in Table 2. The inconsistency of such an approach is also detected in selective labelling of copper minerals as 'metals', as seen for instance in the building E.VIB. $8^{3}$, where two copper minerals were marked as 'metals' in the Mellaart's list (Table 2). We therefore doubt that finds from levels IX and VII were metals in a true material sense of this term, but rather any type of material Mellaart held as related to the idea of metallurgy, such as various colourful minerals. In the light of these inconsistencies in reporting truly metallic finds, we believe that the samples that reached Neuninger et al. were all metal and metal-related samples from Mellaart's excavations. An alternative hypothesis that Mellaart did not send all metal-related samples to Austria could be valid; unfortunately there is no information of whatever the remaining samples are or where they might be located.

Noteworthy is in this regard Mellaart's appreciation for the shared aesthetic appeal of minerals and metals. In his 1964 report he writes: "The discovery of metal ores or native copper at this early date in Anatolia is perhaps not so surprising. The traders and prospectors of Çatal Hüyük roamed far and wide in their search for raw materials, colourful stones, fossils, concretions, etc., and the brilliantly coloured copper ores-a bright blue azurite and the green malachite (?) which ground up into a powder were used in the burial rites in Levels VI and VII - as well as the fine red and heavy native copper, are materials (like lead (galena), haematite, cinnabar, apatite, etc.) conspicuous by their colour and weight, sought after and highly prized" (Mellaart, 1964: 114).
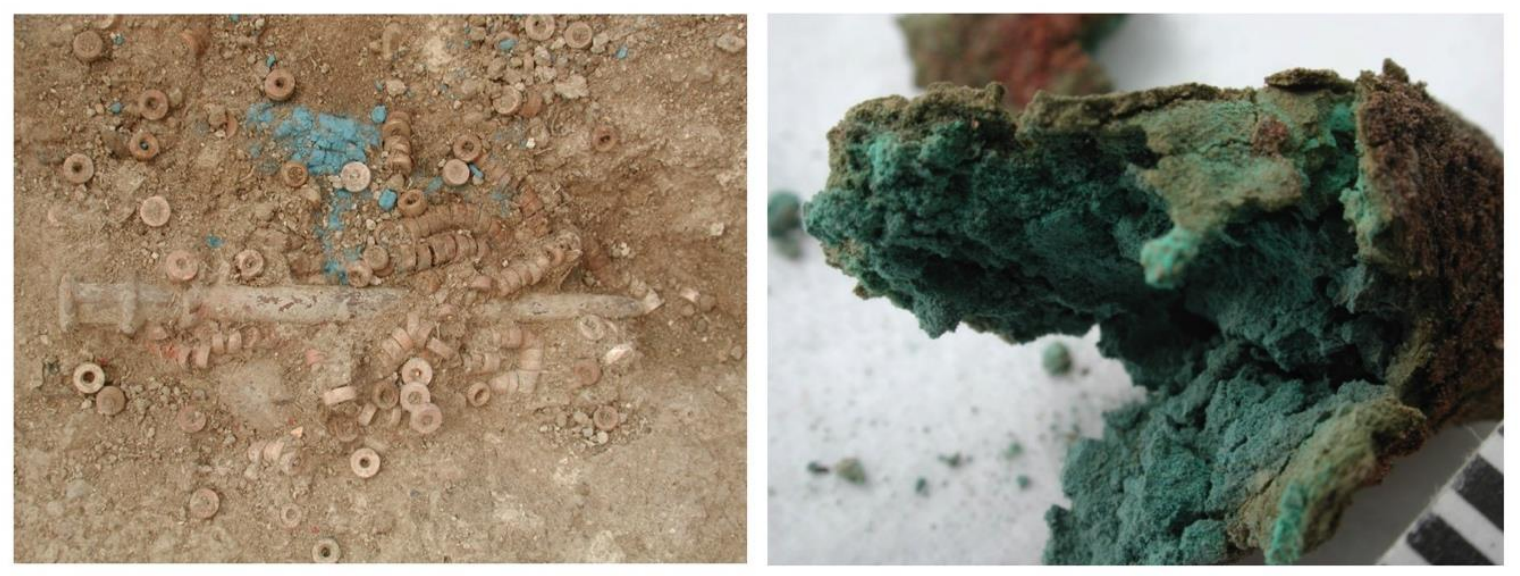

Figure 2: left) Blue pigments (azurite) scattered as lumps in Burial 1202 in Çatalhöyük (campaign 2003). The distribution might have been an indication of deposition as either loose lumps or in a (skin or fabric) pouch that had decayed (courtesy of the Çatalhöyük Research Project); right) Green pigment (malachite) from Burial 757 (campaign 2001) in Çatalhöyük, discovered as a lump that seems to have preserved the shape of the original organic carrier (fabric or skin pouch). Note the crumbly nature of recovered pigment and soil coating (courtesy of the Çatalhöyük Research Project).

\footnotetext{
${ }^{3}$ The numbering convention is as follows: alphabetical prefix indicates the spatial area of excavation (areas A, E \& F), the Roman numeral infix denotes the level and the numerical suffix represents the building number.
} 
Significantly, Mellaart (1964: 92) describes the use of metal-based pigments in 'burial rites'. He (1961: 56) claimed that "green paint was found on three burials in Levels VI and VII. In one case, a male (?), it covered the bones; in another, female, it had been applied to the 'eyebrows' on the skull'. In the same article, he also reported that blue and green powdered azurite and apatite was found in lumps near the skulls of the skeletal remains, and "red and green paint was found in lumps or ready for use in the shells of freshwater mussels". Powdered azurite and malachite were also found in renewed excavations of Çatalhöyük in shapes reminiscent of a small pouch, or scattered as lumps (see examples in Fig. 2, Table S3 in Supplementary Materials), together with miniature bone spatulas, and associated mainly with female and infant burials (Camurcuoğlu, 2015). Detailed microscopic analyses by Camurcuoğlu (2015) revealed that these pigments were coated with clay and iron oxide particles, while angular and sub-angular shapes of either green or blue phases indicated that the pigments might have been hand-ground. The startling predominant evidence of blue-only or green-only phases present in blue and green pigments respectively imply the importance of colour 'purity' that was probably highly sought after and that might have had a particular symbolic meaning. The latter assumption is highlighted by the fact that no blue or green pigments were identified in the wall paintings or any other activity in this site, which leaves us with assumption of their specific ritual role as burial offerings. The context and the results of analyses of Çatalhöyük green and blue powders led Camurcuoğlu (2015) to recognise these as the earliest documented use of malachite and azurite as pigments, anywhere. Red (ochre or cinnabar) is less commonly found in lumps, however, it is also found in powder form staining small containers of shell or stone, or 'painted' onto bones (Mellaart, 1963: 50; Mellaart, 1964: 93; Mellaart, 1966: 183; Angel, 1971).

\subsection{Context evaluation of samples analysed by Neuninger et al.}

Table 1 provides the list of samples that were excavated by J. Mellaart, sent to H. Neuninger for analysis and now form the core of this study. Only samples CHM 11 from Grave 5, building E.VI.1 and galena from building E.VI.29 have been published thus far (Neuninger et al., 1964; Sperl, 1990; 1991). Neuninger et al. (1964: 99, Tab. 1) mention that their team conducted compositional analyses of a further four copper metal (bead) samples, however, no actual field labels were provided, apart from analytical numbers (3862-3865). Out of fortyone samples in total, thirty-six are studied here (labelled CHM and a related number). We received the entire assemblage with an accompanying table designating the context of all finds, and boxes/sections that they belonged to (Table 1, Fig. S1 in Supplementary Materials).

The chronologically earliest samples (CHM 5; CHM 6; CHM 7; CHM 8) are copper-based minerals from a single building E.VII.10 at Level VII, where out of c. forty-four buildings exposed only thirteen were excavated with their complete occupation sequence. This building was revealed in 1963 (Mellaart, 1964), consisting of two spaces (Fig. 1). The larger, eastern space had platforms arranged along three walls, those on the eastern side being separated by benches. A sunken area was defined to the south where the oven was set against the wall towards the 
eastern end with a circular hearth in front. A crawl-hole at the northern end of the west wall led to a narrow western space, which was excavated by the Hodder team (Farid, 2007). The building is recorded as containing animals sunk in relief and animal installations (Mellaart, 1964; 1967). Numerous burials were excavated in the 1965 season, two of which were noteworthy female ochre burials (Angel, 1971). The head of one was reported as being 'entirely covered in red ochre and cowrie shells had dropped out of the eye sockets' (Mellaart, 1966: 183). Whilst there is no indication of any recovered metal objects from this building (see Table 2), samples CHM 5-8 have labels describing them as 'ore lump from House E.VII.10' (CHM 5-6) and as 'copper lumps with soil from House E.VII.10' (CHM 7-8). Neither label specifies the samples as deriving from in situ deposits and indeed, the latter description could imply that CHM 7 and CHM 8 were identified as different from the ore lumps CHM 5 and CHM 6 (Fig. 3), or, alternatively, that they were collected from the infill of the building where a secondary context would not be too far from their primary phase.

The overlying Level VI horizon of buildings was by far the largest exposed comprising c. forty-nine excavated buildings, from which five buildings yielded materials for our study (Tables 1 and 2). At Level VI Mellaart encountered stratigraphic problems such that he reports (Mellaart, 1964: 40), arguing that it was necessary to divide Level VI into Levels VIA (Late) and VIB (Early). Any of these numbering conventions (Level VI, Level VIA, Level VIB) may be encountered in relation to this paper, which have not been changed from the initial numbering in order not to lose original citations. However, for the purpose of this paper all have been stratigraphically validated as Level $\mathrm{VI}^{4}$. It is also at this level that Mellaart reports the end of Level VI as a 'violent destruction' (Mellaart, 1964: 115). He (Mellaart, 1964: 85) also notes: “The conflagration which put an end to Level VI A was of such intensity that the heat of the burning buildings above penetrated to the depth of about 3 feet or more below the floor level of the buildings, carbonizing bodies and burial gifts alike and preventing all further bacterial decay".

Current discourse on burnt buildings from the renewed excavations centre around the debate of deliberate versus accidental burning of buildings (Cessford and Near, 2005; Twiss et al., 2008). The forensic fire examination of these burnt buildings conducted by Harrison et al. (2013) identified a range of mechanisms by which buildings burned at Çatalhöyük involving 'compartment' and 'combustion' fires, which depend on fuel load and thermal characteristics. Experimental work conducted to assess the ability to raise subsurface deposits to such temperatures that fully charred skeletal remains and, in some cases carbonised brain tissue, was undertaken on porcine brain tissue. It demonstrated that a temperature of c. $300{ }^{\circ} \mathrm{C}$ must be maintained over about a two-hour period for the brain tissue to be carbonised but to char bone $30 \mathrm{~kg}$ of timber was required to fuel a fire over an eight-hour period.

\footnotetext{
${ }^{4}$ E.VI.29 \& E.VI.31 were both reassigned to Level VII later in the excavations by Mellaart, although he later kept changing his mind on the assignment of these buildings to Levels VIa, VIb or VII. For the purpose of this report, we keep the original assignment to Level VI, which also matches the labels of the studied samples.
} 
The conclusion is that the duration of burning was the dominant variable in producing carbonisation of bone rather than the peak temperature achieved.
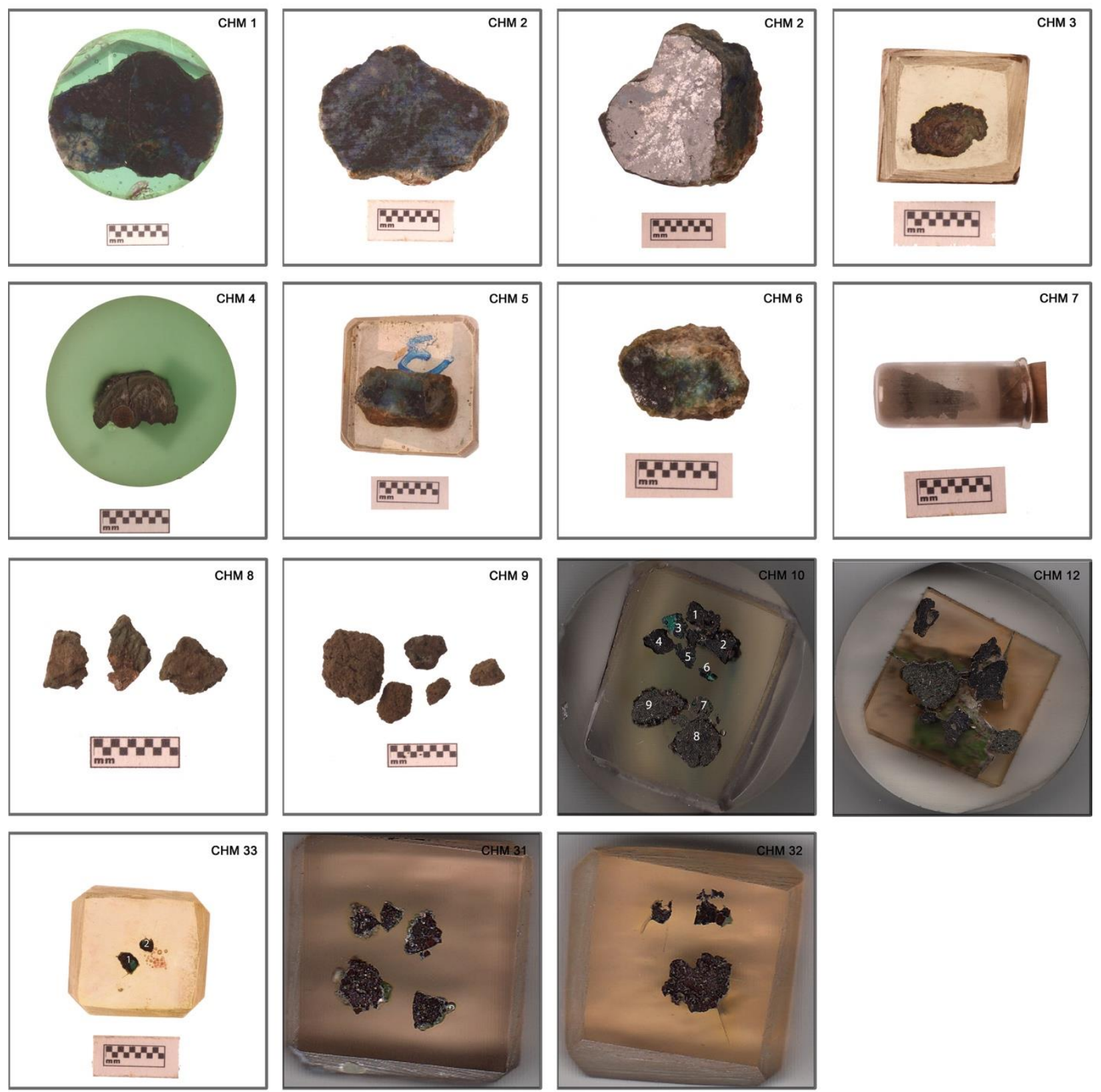

Figure 3. Copper-based minerals and haematite samples. Clockwise: CHM 1, CHM 2 polished, CHM 2 unpolished, CHM 3, CHM 4, CHM 5, CHM 6, CHM 7, CHM 8, CHM 9, CHM 10, CHM 12, CHM 33, CHM 31 and CHM 32.

Building A.VI.1, which yielded samples CHM 1-2 and CHM 13-16, was excavated in 1962 (Mellaart, 1963). Later, it is renumbered on plans as 'shrine 61' in both Levels VI A and VI B (Mellaart, 1964: Fig. 1, 2). The building is shown as a large space with platforms along the north, east and south walls (See S61 in Fig. 1). Along the southern wall was the mark of the ladder and an oven set into the wall, with a hearth in front. A second space seems to have 
been entered through a 'post-and-plaster' screen along the western side. It was embellished with red panels and red-painted grooves. There were two 'bull pillars' and a bench with seven pairs of cattle horns (Mellaart, 1963; 1967). A total of 13 skeletons were excavated from this building (Mellaart, 1967: 205). Mellaart (1964: 95) reports that "women as well as men in Shrine A.VI.1 wore copper finger-rings" (see Tables 1 and 2), which is the only suggestion that rings were found on more than one skeleton in this shrine.

Other artefacts in Shrine 61 included an obsidian lance and arrowheads, two pots and numerous food remains in the anteroom where the floor was covered in matting, as well as the carbonised remains of two circular baskets, a wooden dish with handles, two polished stone maceheads and a painted clay figurine (Mellaart, 1963; 1966; 1967). This was described as "massive remains of a very large shrine of Level VI (A VI. I), which had been destroyed in a tremendous conflagration" (Mellaart, 1963: 50). Such an interpretation was probably based on the presence of two large carbonised roof beams that were recovered in the debris of the main room. Samples CHM 1 and 2 are simply labelled as 'ore lump from Shine A.VI.1' (see Table 1). Samples CHM 13 to 16, however, are labelled as 'beads from the grave in the northern corner of Shrine A.VI.1'. These 'beads', whilst positively associated with a primary context in this building are not, however, associated to a specific grave or platform in the northeast corner. We believe that these beads are the only metal samples available for study from the context of this building, since we could not identify any of the 'copper finger-rings' Mellaart (1964: 95) documented, not even in fragmented state (see below Fig. 7).

Shrine E.VI.1 is the building from which samples CHM 9-12 originate. It was excavated in 1961 (Mellaart, 1962) as a three 'room' building. A small northwestern room had two storage features along its east wall and was accessed from a crawl-hole at its western end. The larger, central, space had platforms along the east wall. A recess in the southern space marked the place of an oven with a hearth in front and a possible large storage bin in the southeastern corner, which Mellaart generally described as 'plaster bins for grain' (Mellaart, 1963: 45). Several wall paintings of symbols, kilim/textile patterns, and simple patterns were revealed. There were also reliefs of a goddess, a female breast, a possible animal-head and horns set along the edge of a bench (Mellaart, 1967). Thirty skeletons were recorded as being excavated (Mellaart, 1964) from this building, although only 25 were studied by Angel (1971), of which one male and four female skeletons were carbonised black. In addition, fragments of charred textile were recovered and carbonised cloth found inside the skull of one (Burnham, 1965). These are the only references corroborating that the building had 'been replastered after a fire' (Mellaart, 1963: 59). A necklace of fine limestone and carved serpentine beads were found with a female skeleton and a bone belt-set from another burial. Other artefacts from within the house included pottery, a double-pointed 'willow-leaf' obsidian point, eight other projectile points, a lancehead (Bialor, 1962), two stamp seals and a wooden box with a lid (Mellaart, 1964; 1967). Samples CHM 9 to 12 are labelled as originating from 'Grave 5 from the central platform, House E.VI.1'. As there is only one central platform in this building, against the eastern wall, it is with some certainty that we can assign Grave 5 to that platform, but no further information is available on the number of graves that cut the platform 
or the stratigraphic location of Grave 5 within the platform. The same is therefore valid for samples CHM 9 to 12; we do not know which buried individual were they associated with except that these samples were reported as a potential burial offering. We also do not know if the individual buried in Grave 5 was carbonised black after a fire, although we are aware that the fire reached up to c. $90 \mathrm{~cm}$ (3 feet) deep 'carbonising bodies and the burial gifts alike' (Mellaart, 1964: 85). Sample CHM 11 was identified as copper slag by Neuninger et al. (1964), prompting Mellaart (1964: 114) to suggest that the process of copper smelting might have been known at the time.

The neighbouring building to the east, E.VI.8, was excavated in 1962 (Mellaart, 1963) and at the end destroyed by fire (Mellaart, 1964: 40). The largest of three rooms in this building led into to a southeastern room through a crawl-hole, which led in turn via another crawl-hole to a southwestern room. The southeastern area appears to have contained a central circular hearth or basin as well as a sub-rectangular hearth in the southwest corner. The larger room had platforms along its north and east walls, with a bench between the two most southerly. Mellaart (1967) reported a sunken animal relief, a goddess, an animal-head, bucrania, and breast reliefs, as well as a pattern of hands and a red 'net' design on the east wall. Fifteen skeletons were excavated, four of which were carbonised black (Angel, 1971). Mellaart (1963: 95) also mentions a burial whose complete corpse was covered by red ochre. A fragment of charred textile was recovered (Burnham, 1965: 172), together with two greenstone celts and two ceramic pendants from female burials. Also, a recovered assemblage includes a wooden spoon from a burial, an obsidian pendant, lignite beads and a red sandstone spouted dish. The label for samples CHM 3 and 4 describes these as 'copper lumps from grave 2 at E.VI.8' but again, we do not have further contextual information on which platform 'grave 2' was located.

Separated by two buildings, E.VI.31 was excavated in 1962 (Mellaart, 1963). It consisted of a large space with two small spaces entered by crawl-holes to the north (see Fig. 1). The larger space had two platforms along the east wall ending in a bench and a possible platform against the west wall. To the south lay an oven with two hearths and a platform in the southwest corner. There was also an installation of two superimposed bull's heads between two plastered posts with other features above (Mellaart, 1963). The presence of burials was indicated only on Table 13 (Mellaart, 1967: 81), and therefore the number is unknown. Mellaart (1963) records that the building was destroyed by fire but provides no further information. The samples CHM 29 and 30 from this building are labelled and described as 'two beads from a burial, Shrine E.VI.31', and as such it is not possible to identify which of the four possible platforms this 'burial' may have been located in.

Neighbouring to the north, E.VI.29 was also excavated in 1962 (Mellaart, 1963). This was a single space demarcated into four with a possible sunken southeast quadrant where the oven was located. A platform possibly lay to the northeast with a series of features in the southwest corner. It may have had a relief on its western wall. Ten skeletons were studied from this building (Angel, 1971), and a white marble dish and flint dagger were recorded as being found with a male burial. Another male burial was found with a bone or horn scoop, and a bone belt-set was found from another burial. There is no mention of a fire or burning and the occurrence of 'metal' from 
this building is recorded on Table 13 (Mellaart, 1967: 81) only. The label 'lead from Grave E.VI.29' accompanies samples CHM 17 to 28 (Table 1). The location of the grave within this building is, again, unknown. Although initially identified as 'lead metal', they were since shown as made from cerussite and galena, minerals rich in lead, but not lead metal (Sperl, 1990).

A further five samples (CHM 31 to 35, haematite and copper-based minerals), CHM 36 (obsidian) and CHM 37 (a 'green' sample) have simply been labelled as coming from 'Level VI', and as such are a group of un-provenanced samples albeit but all being from Level VI and therefore relatively significant for this study.

A further eight buildings are indicated in Table 13 (Mellaart 1963: 81) as having yielded 'metal' but from which no material was exported for analysis by Neuninger et al. Chronologically, the earliest mention of 'metal' comes from Level IX, from where in Shrine E.IX.1 Mellaart records that a female was covered in red ochre, cinnabar was applied to her skull and with her 'were several necklaces and some copper and lead beads, the earliest found on the site' (Mellaart, 1964: 93; 1967: 207). At Level VI a burial of an adult woman and child from building E.VI.25 is described as containing patches of carbonised textile, including 'many fragments of a string-skirt the ends of which appear to have been encased in thin copper tutuli to weight it down' (Mellaart, 1963: 101; 1967: 219). 'Metal' from another Level VI building is reported from E.VI.5, from which Angel (1971: 79) studied 19 skeletons. One male and three females were carbonised black. Many of the bones were wrapped in textile of various weaves and fineness, and tied into bundles with tapes. One skull was wrapped in textile soaked in red ochre. No pottery was found in this pit, but two polished bone pendants, a small copper roll, and a number of carbonised wooden vessels were recovered (Helbaek, 1963). Finally, the presence of metal from the following six buildings is shown in Mellaart's Table 13 only (Mellaart, 1967: 81): E.VII.35, E.VIB.10, E.VIB.12, E.IV.8 and the chronologically latest, in A.II.1.

Other references to 'metals' emerge throughout Mellaart's reports and publications in general discourse and overview of technology, craftsmanship and ritual. He asserts that the use of two metals, copper and lead was familiar at least as early as Level IX, and that "lead beads and pendants, especially in Levels VII and VI, and copper was used for beads, pendants, finger-rings, small tutuli which enclosed the lower ends of string skirts (in VI), small tubes (VII) and possibly pins and awls in Level II." However, it was the occurrence of a "supposed lump of copper ore from House E VI A, that proved to be not ore, but copper slag, suggesting that the process of smelting may already have been known, by the middle of the 7th millennium, but further analyses are required to establish how usual this was" (Mellaart, 1964: 111), that is finally being addressed in this paper.

Whilst from today's perspective the reporting of the 'metal' finds is limited and frustrating, for the time when Mellaart was conducting his excavations, the discovery was practically a unique one, which he dealt with within the recording and analytical tools available at the time. Due to the absence of detailed locational or contextual data 
it is not possible to ascertain veracity of the exact find spots for all of the re-analysed metal samples; however, for the first time we were able to gather all relevant information for their context in the text above.

The most recent analyses of three Neolithic copper beads from the East Mound by Birch et al. (2013) further attest the presence of copper metal artefacts on this site from levels II to VI, with a greater contextual precision (see Table S4 in Supplementary Materials). Five pieces of metal were analysed, belonging to three distinctive groups of fragmented beads and rings from both burial and infill/dump deposit layers. They were found to consist of hammered and annealed pure copper metal, rolled up to form beads which contained only traces of $\mathrm{Ag}$ (up to $\mathrm{c}$. $300 \mathrm{ppm}$ ) and As (up to c. $90 \mathrm{ppm}$ ) in two ring fragments (Birch et al., 2013: 309, Tab. 17.2). Given the low concentrations of trace elements such as cobalt, nickel, antimony and lead in these objects, it is argued that they were most likely made from native copper (Birch et al., 2013; cf. Pernicka et al., 1997). The working evidence corroborates the findings of Neuninger et al. (1964), matching the common metal working practice in Anatolia from as early as the $8^{\text {th }}$ mill cal BC (e.g. Stech, 1990; Maddin et al., 1991).

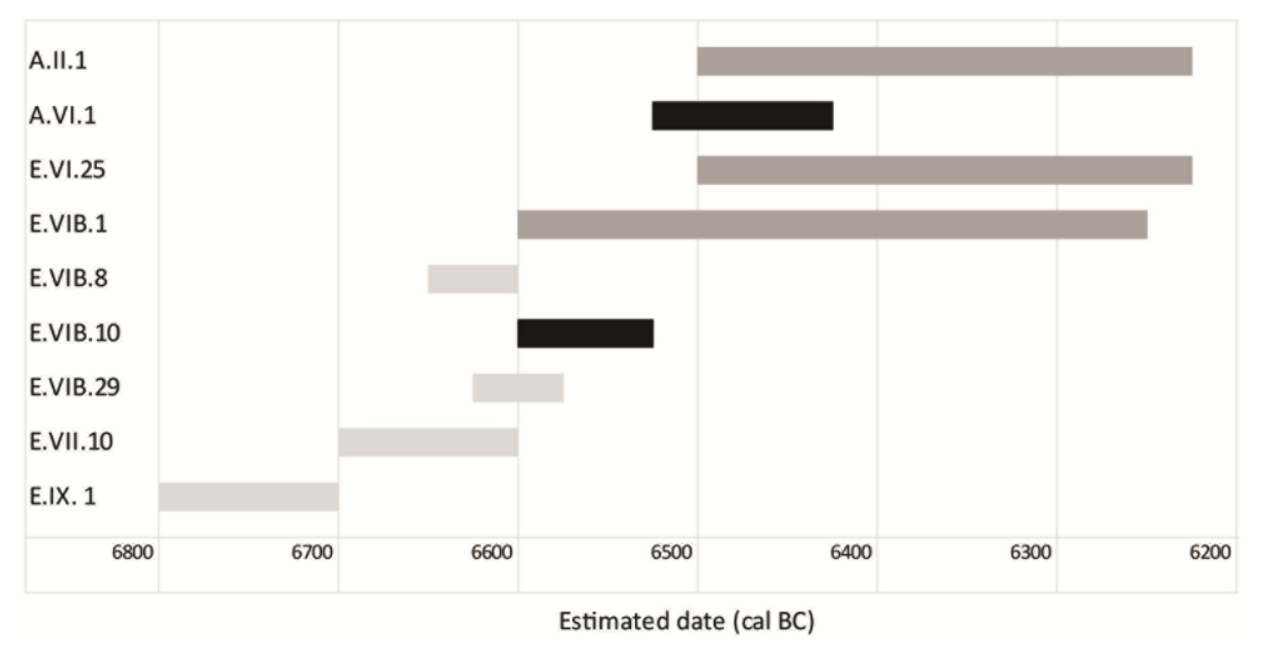

Figure 4: Estimated dates for buildings that yielded metal-related finds (black: derived from wiggle-match of floating tree-ring sequence; dark grey: calibrated radiocarbon dates; light grey: derived from interim chronological model for ongoing dating project).

The dating of the site in the 1960s is based on radiocarbon measurements of 27 samples that spanned buildings from all levels, of which eight were from buildings that contained metallurgical finds. These radiocarbon dates have been combined with Mellaart's phasing scheme of successive building levels in a Bayesian chronological model, which estimates the dates of those levels (Cessford, 2005: 66-79). The stratigraphic integrity of these levels, however, is under review by a current programme of radiocarbon dating and Bayesian modeling. This is attempting to combine the stratigraphical sequence of buildings and open areas with a large series of carefully selected radiocarbon dates, from both the renewed excavations and the 1960s archive. Both the radiocarbon dating and stratigraphic programmes are on-going and only partially reported (Bayliss et al., 2015; Marciniak et al., 2015); 
nevertheless, this project has thus far obtained radiocarbon dates for four buildings from which Mellaart reports metallurgical finds and has stratigraphic evidence allowing seven to be included in the Bayesian chronological model (for a detailed account see Supplementary Materials). This model provides a more detailed account of chronology of Level VI in indicating that it does not form a concentrated chronological horizon (Fig. 4). A.VI.1, for example, appears to be about a century later than E.VIB.8 and E.VIB.29, and overall buildings assigned to Level VI appear to fall anywhere between the $67^{\text {th }}$ and $64^{\text {th }}$ centuries cal BC. On current evidence, it appears that metal and metal-related finds occur at Çatalhöyük across much of the seventh millennium cal BC (A. Bayliss, pers. comm.).

\section{Materials and Methods}

\subsection{Characterisation of minerals and metal finds in Çatalhöyük}

The assemblage of samples received consists of 41 items in total, 36 from Çatalhöyük, 4 from Hac1lar and one that turned out to be a modern slag piece (see Supplementary Materials for further detail). It includes copper-based minerals, crumbs of copper-based 'slag', galena minerals, galena and copper metal beads, a piece of obsidian, and a green stained piece of bone (?). We concentrate below only on copper-based minerals, copper metal beads and the copper 'slag'.

Copper-based minerals include CHM 1 to 10, 12 and 33 (Table 1, Fig. 3). Their macroscopic appearance varies in relation to the context. The 'free' building finds (CHM 1, 2, 5 and 6) are of similar appearances both as free and as mounted samples: they are lumps of minerals $1-2 \mathrm{~cm}$ in length, with blue and green streaks coming through the pale surface of amorphous samples, while the polished surfaces expose a mix of dark body with green/blue components. Samples CHM 7 to 10 and 12 come from either a domestic (E.VII.10) or funerary context (E.VI.1), and although originating from different levels, they share a similar appearance, being coated with soil, granular and crumbly green materials a few millimetres wide. Samples CHM 3 and 4 come from a burial, and are up to 1 $\mathrm{cm}$ long lumps of green and red components visible on the polished surface. We studied in more detail samples CHM 1, 3 to 5, 9, 10, 12 and 33. Resin blocks with samples CHM 9, 10, 12 and 33 consist of several similarlooking items (ranging from 2 to 9), which we refer to as 'locations' in our analyses (see Fig 3).

The 'slag' sample CHM 11 belongs to a batch of items from the central platform, Grave 5, building E.VI.1, which consists of a dozen non-magnetic crumbly copper-based minerals (here embedded in blocks CHM 9, 10 and 12) in addition to this one. Sample CHM 11 consists of 15 smaller items marked as 'locations' (Fig. 5) in our microstructural and compositional analyses, giving each item a unique number. According to the images available to us from the previous study, we believe that CHM 11 is the sample Neuninger et al. (1964: 100) identified as 
'slag debris with molten copper oxide'. Neuninger and collaborators (1964: 99, Tab. 1) identified traces of Ni, Zn, As and Co in the mentioned sample, while Sperl in $1997^{5}$ identifies antimony in it as well.

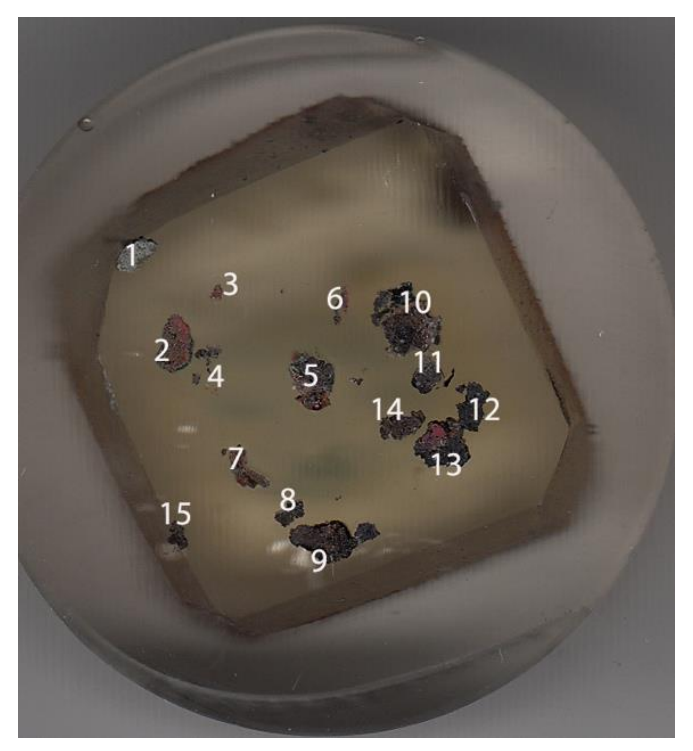

Figure 5. Copper 'slag' sample CHM 11 with marked 'locations'

Copper metal beads (CHM 13 to 16, 29, 30, 34 and 35) originate from two burial contexts in buildings A.VI.1 and E.VI.31 respectively, while CHM 34 and CHM 35 come from the soil of Level VI. The richest collection of metal beads comes from the burial in building A.VI.1; we estimate there are c. 53 copper metal beads, although the exact number is difficult to assess due to the heavy corrosion and fragmentation of these artefacts (Fig. 6). The beads are either of a short, circular shape, or tubular, common for the period and with a long history in the region of origin (e.g. Maddin et al., 1999). We studied in more detail samples CHM 14, 15 (joint block with CHM 30), CHM 34 and 35, while CHM 13 and 16 were analysed for provenance only (see Table S2 in Supplementary Materials). The published analyses of four of these metal beads identified high purity copper metal with traces of $\mathrm{Ag}$ (Neuninger et al., 1964: 99, Tab. 1) without specifying which samples these were. In addition to the described set of samples, we also analysed two blocks with several samples of mineral haematite (CHM 31 and 32, Fig. 3), which are not further considered here. Also, the analyses of galena minerals and beads will be presented separately elsewhere.

\footnotetext{
${ }^{5}$ We found this information as a note on what appears to be a poster presentation by G. Sperl, titled "New Research on the Beginnings of Metallurgy at Çatalhöyük, Turkey ( $7^{\text {th }}$ mill BC)", presented at Harvard University in 1997.
} 

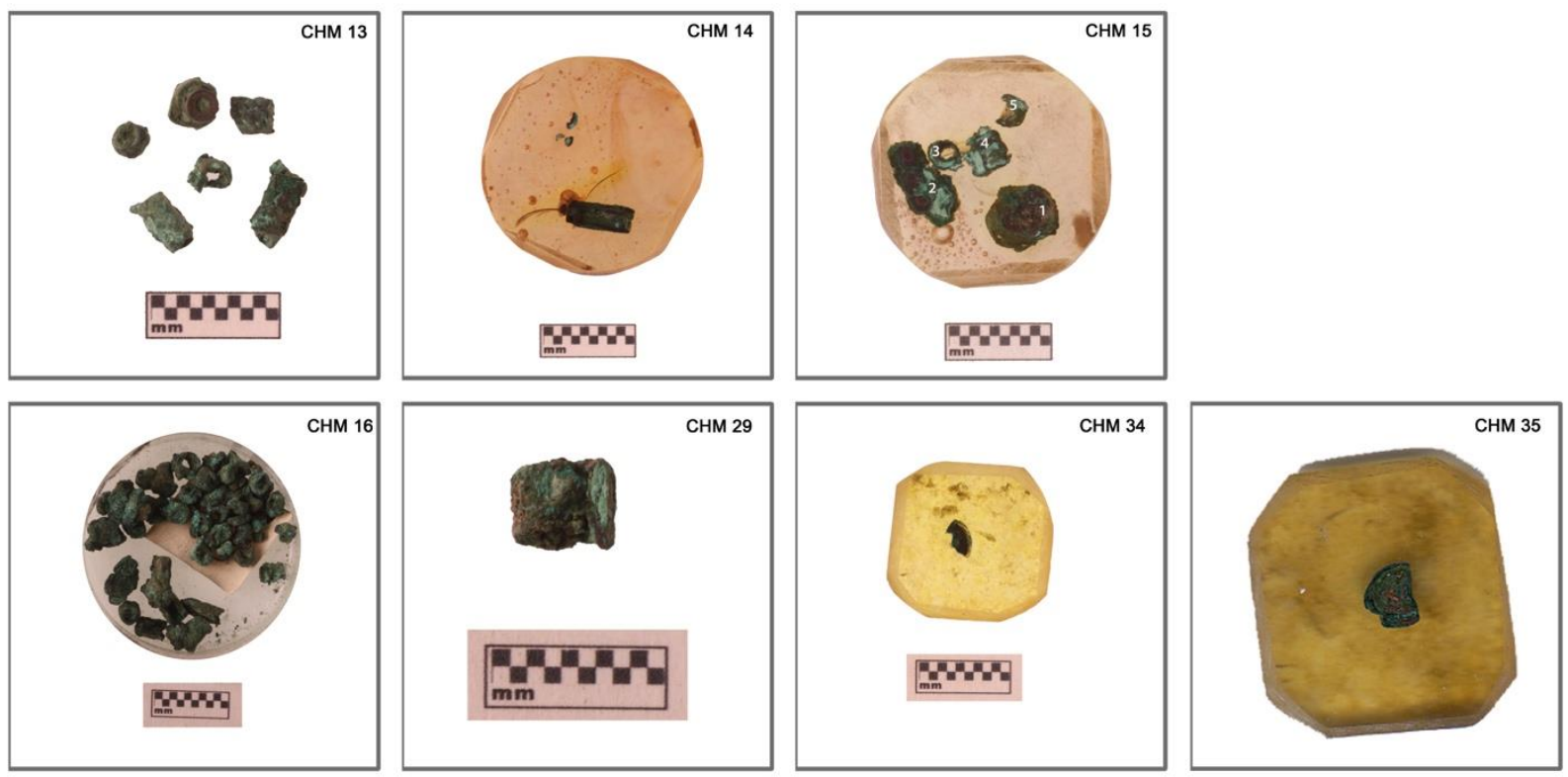

Figure 6: Copper metal. Clockwise: CHM 13, CHM 14, CHM 15 \& CHM 30 (CHM 30: loc. 1 and CHM 15: loc. 2-5), CHM 16, CHM 29, CHM 34, CHM 35.

\subsection{Methods}

In total, we analysed 19 samples for microstructure, chemical composition and possible provenance (as indicated in Tables 1 and S2), out of the assemblage consisting of 36 samples excavated by J. Mellaart in Çatalhöyük in the 1960s, including some that had already been analysed by Neuninger et al. (1964) and Sperl (1990). Of these 19, 18 belong to Neolithic Çatalhöyük, while one (CHM 27) is a modern slag sample that might have ended up accidentally in this collection. A further five samples (CHM 6, 7, 8 and 29) were only characterised macroscopically. Table S2 indicates that we have also conducted analytical work on galena samples, which we will report in a separate article.

In total, we analysed all existing polished blocks (16 samples were already mounted in 15 blocks that were re-cast and re-polished by us), together with a freshly made block (CHM 9) for microstructure and composition with OM (Optical Microscope) and SEM-EDS (Scanning Electron Microscope with Energy Dispersive Spectrometer) at the Wolfson Archaeological Science Laboratories, UCL Institute of Archaeology, London. Provenance and trace element analyses were conducted with MC-ICP-MS (Multi-Collector Inductively-Coupled Plasma Mass Spectrometer) and LA-ICP-MS (Laser Ablation Inductively-Coupled Plasma Mass Spectrometer) at the CurtEngelhorn Centre for Archaeometry in Mannheim, Germany (see Supplementary Materials).

Copper-based minerals studied here are recognised as only potentially representing copper ores, which is why we kept the neutral term 'mineral'. We see ore as a culturally and economically defined term referring to agglomerations of minerals from which the extraction of one or more metals is seen as a profitable action (Rehren, 
1997; Rapp, 2009). The importance of this distinction of copper minerals in the context of potential pyrometallurgical activities has already been recognised by Muhly (1989), who noted that the presence of malachite at an archaeological site has little to do with copper metallurgy, as much as the presence of haematite in a cave painting context has nothing to do with iron metallurgy. The only potential evidence of extractive metallurgy, CHM 11, we termed 'slag' with quotation marks because we question here the nature of its creation.
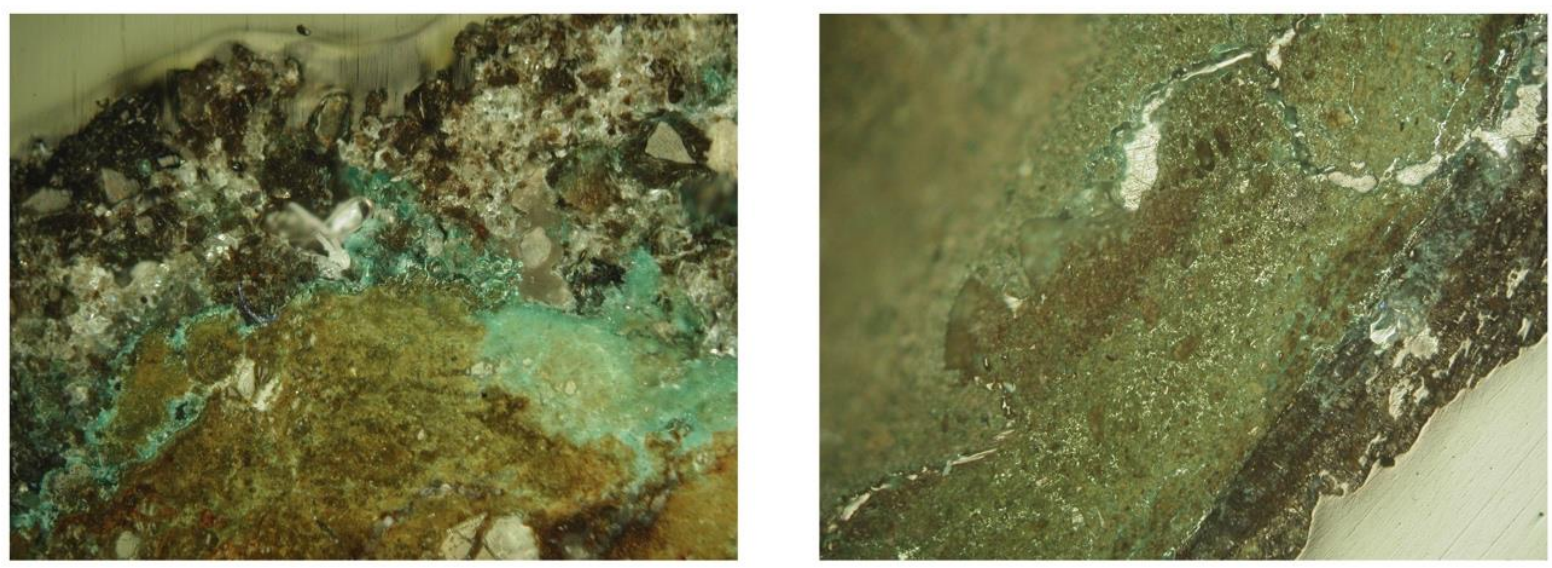

Figure 7: left) Photomicrograph of CHM 3 under cross polarised light (magnification 50x, width 3.2mm). Note the green matrix rich in copper content; right) Photomicrograph of CHM 4 under cross polarised light (magnification 50x, width $3.2 \mathrm{~mm})$.
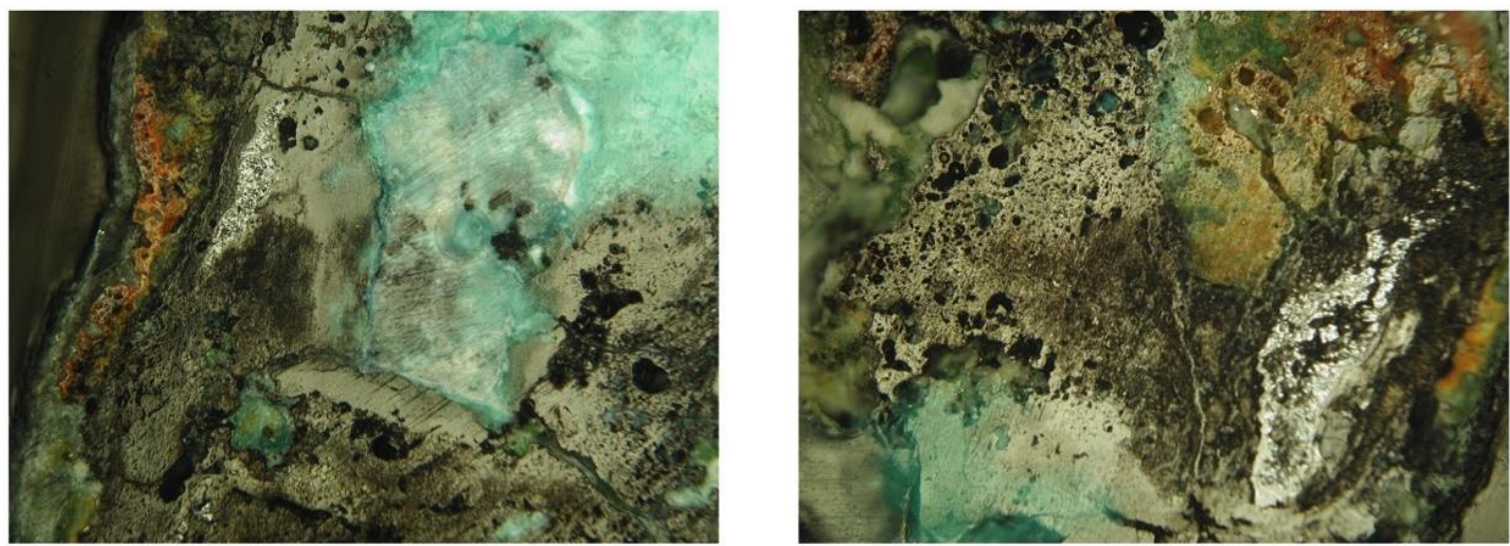

Figure 8: left) Photomicrograph of CHM 33 (location 1) under cross polarised light (magnification 100x, width 1.6mm); right) Photomicrograph of CHM 33 (location 2) under cross polarised light (magnification 100x, width $1.6 \mathrm{~mm})$. Note green copper-rich phases in both locations in this sample. 


\section{Results}

\subsection{Copper-based minerals}

The copper-based minerals form two distinctive groups: oxide (CHM 3, 4, 9, 10, 12 and 33) and sulfide (CHM 1 and 5) minerals. Macroscopically, they differ in texture: while oxide minerals are small-sized and crumbly, the sulfide examples are solid lumps of ore (Fig. 3). The oxide minerals contain a predominant copper-rich phase (see Figures 7-10) with only traces of zinc found in CHM 9 and 10 (Table 3). Besides the copper-rich matrix, both CHM 9 and CHM 10 contain phases with various antimony and antimony and arsenic readings respectively (Table 4). These phases contain lead and various levels of $\mathrm{Cu}$, pointing at the composition of minerals that belong to the lead-bearing arsenates and vanadates (Dana and Ford, 1922).

The composition of the Sb-bearing mineral phase in CHM 9 is close to valentinite $\left(\mathrm{Sb}_{2} \mathrm{O}_{3}\right)$, however the calcium and lead components classify it as more likely as a mineral of romeite group, or a similar mineral that belongs to the family of antimonates, arsenates and vanadates. This could have originated as a weathering product of primary stibnite $\left(\mathrm{Sb}_{2} \mathrm{~S}_{3}\right)$, with lead and calcium precipitating from the surrounding geological environment. Stibnite is usually accompanied with various other antimony-bearing minerals produced by its alteration, and significantly for this context, occurs with sphalerite, galena or cinnabar (Dana and Ford, 1922: 359); this could explain the presence of lead in the phase observed here. The common denominator for these secondary minerals is the antimony content, while their outer appearance varies from pale yellow to olive green tones.
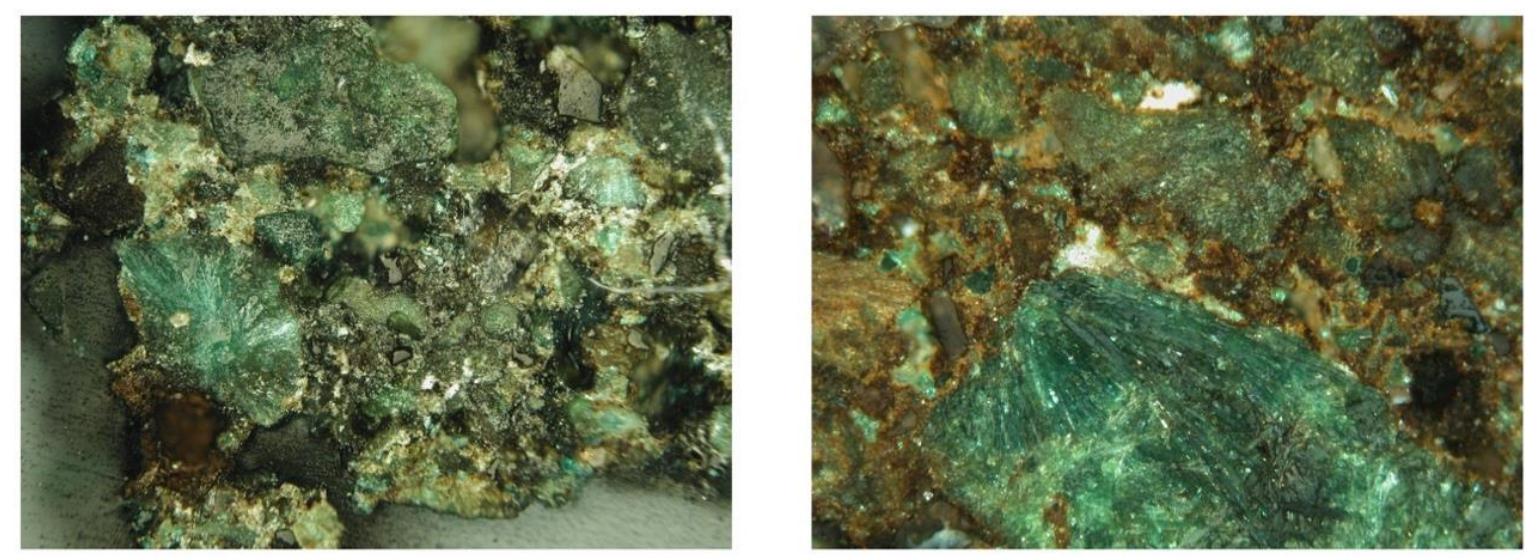

Figure 9: left) Photomicrograph of CHM 9 under cross polarised light (magnification 100x, width 1.6mm). The green phases are rich in copper, while white/bright ones are antimony oxides; right) Photomicrograph of CHM 10 (location 2) under cross polarised light (magnification 100x, width $1 \mathrm{~mm}$ ). The white/bright phases have significant levels of Sb, $\mathrm{As}, \mathrm{Pb}$ and $\mathrm{Cu}$. Both samples appear coated in soil and rich in iron oxides (orange/red). 
A macroscopically similar mineral phase in CHM 10 reveals significant readings of antimony, arsenic and lead besides copper, and is a potential member of the same mineral group as the similar phase in CHM 9, romeite, with variations including cuproromeite (with $\mathrm{Cu}$ ), oxyplumboromeite (with $\mathrm{Pb}$ ) and oxycalcioromeite (with $\mathrm{Ca}$ ). Since the copper content is significant in this phase, the green-olive tint prevails. Broadly speaking, all minerals in CHM 9 and CHM 10 could be weathering products of lead-bearing sulfidic ores deposit including fahlore-type minerals. The same may apply for CHM 12, given that the sample was discovered together with CHM 9 and CHM 10, and bears microscopic and macroscopic resemblance.

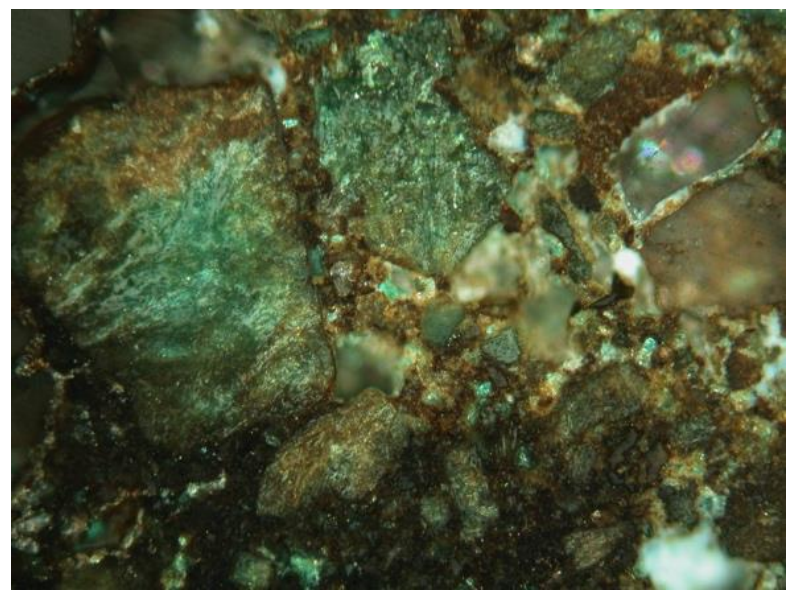

Figure 10: Photomicrograph of CHM 12 (location 3) under cross polarised light (magnification 100x, width 1 mm). Similarly to sample CHM 9 (Fig. 10), this sample is mixed with soil and iron oxides (orange/red).

The copper minerals with high sulfur content are CHM 1 and 5 (Figure 11). Compositionally, they represent a mixture of copper oxides/carbonates and sulfides, with high readings of arsenic, antimony, zinc and iron between them (Tables 5 and 6). The copper oxide/carbonate phases are optically dark and light grey, with the latter compositionally resembling olivenite ( $\mathrm{Cu}: \mathrm{As}$ is roughly 2:1), with some zinc (Table 5). Olivenite $\left[\mathrm{Cu}_{2}\left(\mathrm{AsO}_{4}\right)(\mathrm{OH})\right]$ is a relatively common secondary copper mineral usually found in the oxidized zones of copper deposits containing arsenic-bearing phases, particularly tennantite, enargite, and others. The colour of this mineral varies from olive green to yellow and dark green (Dana and Ford, 1922: 603). A similar colour is also found in zinc-bearing olivenite $\left[\mathrm{CuZn}\left(\mathrm{AsO}_{4}\right)(\mathrm{OH})\right]$.

The composition of sulfidic phases in both CHM 1 and 5 (Table 6) is closest to stibioenargite $\left[\mathrm{Cu}_{3}(\mathrm{Sb}, \mathrm{As}) \mathrm{S}_{4}\right]$, or antimony-bearing enargite, which is chemically close to the tennantite and tetrahedrite (=fahlore) series, altogether classified as sulfosalts, generally similar to the phases observed in CHM 9 and 10. The colour of these minerals is usually steel grey, or dark, as observed in the cross-sections of samples in Fig. 3. Overall, and despite the general compositional differences, minerals CHM 1, 5, 9 and 10 (and possibly 12) could have originated from a similar deposit of lead and zinc-bearing fahlores, with oxidic minerals collected from near-surface weathering zones. Their 
aesthetic appeal could have been the decisive factor in the initial selection, particularly given that the green component was predominant (copper), mixed with metallic-grey enargite. The latter could have also resembled galena, which was also used at Çatalhöyük.
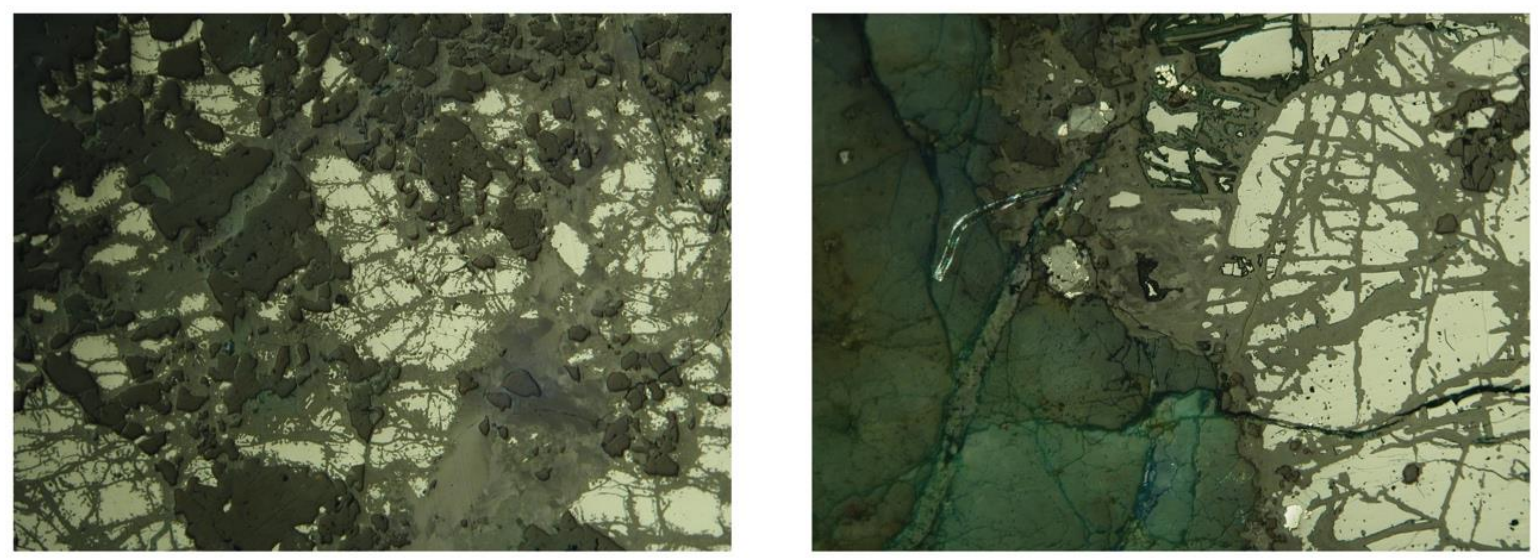

Figure 11: left) Photomicrograph of CHM 1 under cross polarised light (magnification 50x, width 3.2mm); right) Photomicrograph of CHM 5 under cross polarised light (magnification 50x, width 3.2mm). The white/bright phases have significant levels of $\mathrm{Sb}, \mathrm{As}, \mathrm{Pb}$ and $\mathrm{Cu}$. The pale/white phases in both samples are sulfide-rich one, most likely $\mathrm{Sb}$-bearing enargite. The grey and light grey phases are copper oxides with varying levels of As, Sb and $\mathrm{Zn}$.

\subsection{Metallurgical 'slag'}

Neuninger et al. (1964) had identified one 'slag' sample in the analysed assemblage, CHM 11. Although this sample consists of 15 small items (each given a location number, see Fig. 5), they probably originate from the same crumbly lump, given that their structural characteristics are very similar. Interestingly, Neuninger et al. (1964) do not mention more than one 'slag' sample. The first impression from microstructural examination is that there is very little corrosion visible. Some locations, like No. 5 (Fig. 12f) contain copper corrosion products in their core, while there is little to none preserved on the outer edges on any other (for example see Figures $12 \mathrm{j}$ or 121).

The most common feature in all locations are pale pink particles of metallic copper, which were, judging by their distinctive morphology formed in situ (Figures 12b, 12c, 12f, 12g, 13c), and never fully liquid. The reduction of copper ore to copper metal can happen at the solid state at temperatures from c. $700{ }^{\circ} \mathrm{C}$ upwards (Pollard et al., 1991), while the melting of copper metal requires temperatures in excess of $1083^{\circ} \mathrm{C}$. Hence, the clusters of metallic particles in our case are most likely a testimony of a solid-state process of reduction of copper oxide into copper metal, or one that happened at the threshold of conditions required to produce fully liquid copper metal. 

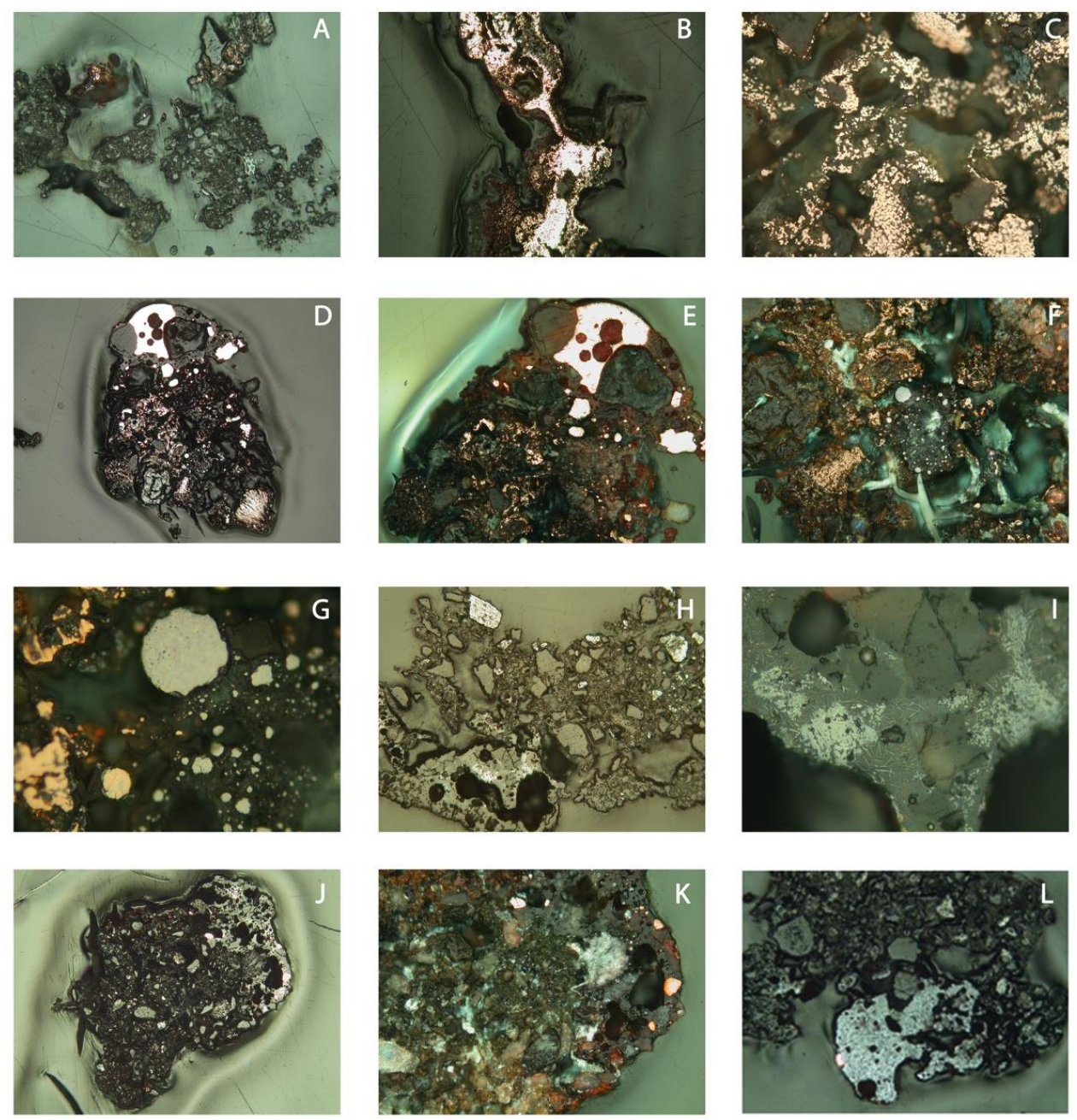

Figure 12: Photomicrographs of various locations in sample CHM 11 taken under both plain (ppl) and cross polarised (xpl) light.a) Photomicrograph of location 4 (magnification 100x, width $1 \mathrm{~mm}$, ppl). Note 'cold' core of the sample and metallic copper on its periphery, with cellular structure of a remaining charcoal (light grey); b) Photomicrograph of location 7 (magnification 100x, width $1 \mathrm{~mm}, \mathrm{ppl}$ ). Note globules of metallic copper formed in situ, surrounded by copper oxides; c) Photomicrograph of location 2 (magnification 500x, width $0.34 \mathrm{~mm}$, ppl). Note globules of metallic copper formed in situ; d) Photomicrograph of location 5 (magnification 50x, width 3.2mm, ppl). Note metallic copper suspended in a slag matrix (top) and a mix of quartz and metallic copper formed in situ in centre and bottom; e) Photomicrograph of location 5 (magnification 50x, width $2 \mathrm{~mm}, \mathrm{xpl}$ ). Note metallic copper and slag matrix (top) and 'cold' centre with metallic copper globules and corroded copper (oxide/carbonate); f) Photomicrograph of location 5 (magnification 100x, width 1mm, xpl). Note white metallic globules in a grey matrix (centre) surrounded by globules of bright copper metal and copper oxides (green and red phases); g) Photomicrograph of location 5 (magnification 500x, width $0.2 \mathrm{~mm}$, ppl). Note bright metallic globules with light grey and grey eutectic phases surrounded by copper metallic globules; h) Photomicrograph of location 8 (magnification $100 x$, width $1 \mathrm{~mm}, \mathrm{ppl})$. Note 'cold' core and top of the sample, and slag matrix at the bottom left periphery; i) Photomicrograph of location 8 (magnification $500 x$, width $0.2 \mathrm{~mm}, \mathrm{ppl}$ ). Note under higher magnification lathes of delafossite and spinel agglomerations embedded in slag matrix; j) Photomicrograph of location 11 (magnification 50x, width 2mm, ppl). Note 'cold' core and top right corner of the sample with slag matrix and metal prills embedded in it; k) Photomicrograph of location 11 (magnification 100x, width $1 \mathrm{~mm}$, xpl). Note heterogeneous 'cold' core with green patches of corroded copper, and 'hot' periphery with slag, copper metal and copper oxides; l) Photomicrograph of location 13 (magnification 50x, width $2 \mathrm{~mm}, \mathrm{ppl})$. Note 'cold' core and 'hot' periphery at the bottom with cuprite and a metal prill. 

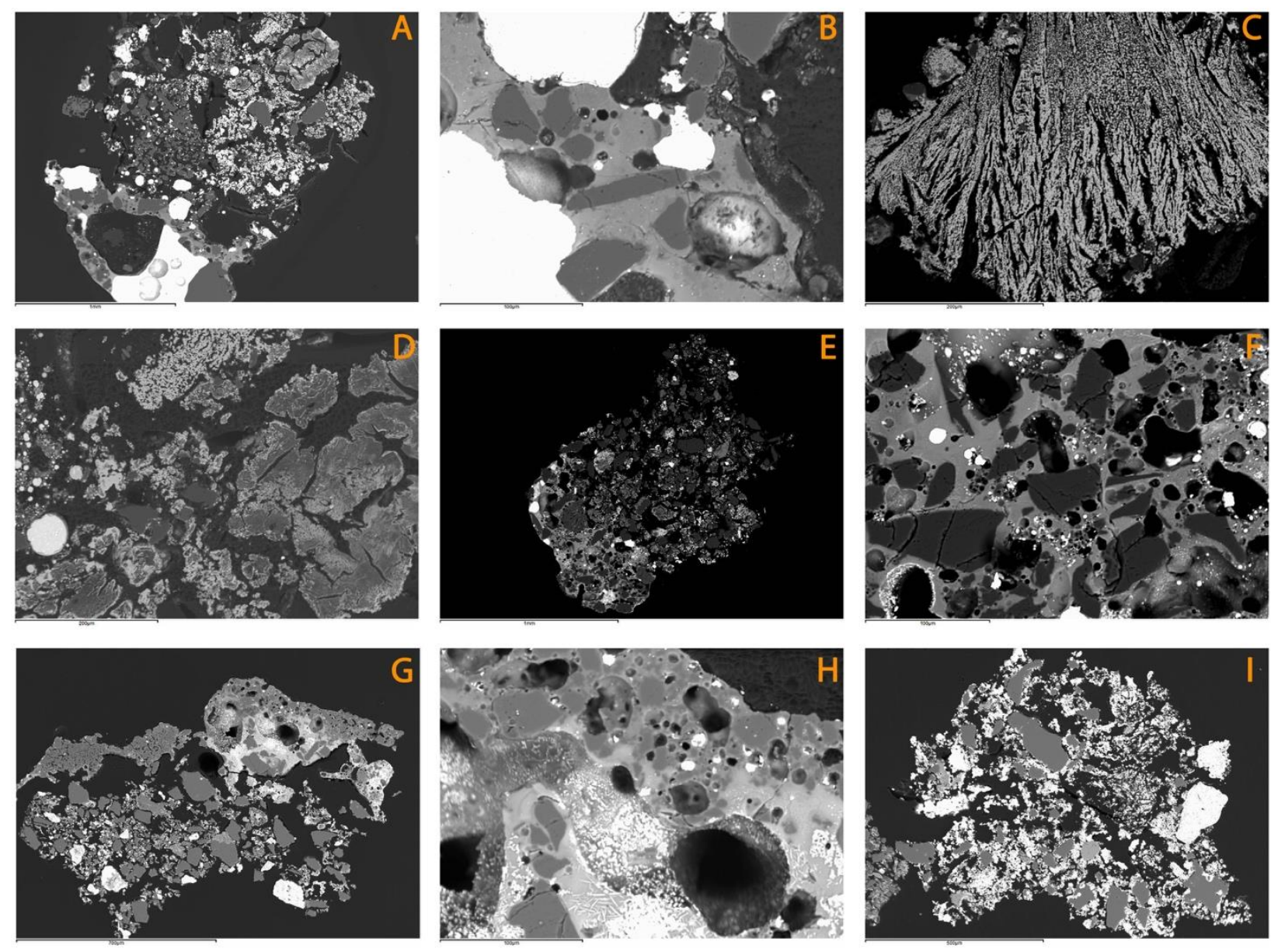

Figure 13: Backscattered electron images of four different locations (left to right): 5, 11, 8 and 9 in sample CHM 11. a) Location 5 (magnification $45 x$, width $2.5 \mathrm{~mm}$ ). Note slag matrix (light grey) with partially reacted (dark grey) and metallic phase (bright) in the bottom part, and a mix of metallic globules (dross) and quartz in the middle; b) Location 5 (magnification 400x, width $250 \mu \mathrm{m}$ ). Note bright copper metal phases and partially reacted quartz (dark grey) embedded in slag matrix; c) Location 5 (magnification 250x, width $450 \mu \mathrm{m}$ ). Note bright copper metallic globules forming within the mineral-like structure of copper oxide present in this sample; d) Location 5 (magnification 200x, width $450 \mu \mathrm{m}$ ). Note a mixture of convoluted agglomerations of copper oxide mixed with bright globules of copper metal and a light grey metal prill in the left bottom corner (antimonial copper); e) Location 11 (magnification 50x, width $2.5 \mathrm{~mm}$ ). Note slag matrix (light grey) with copper metal prills (bright) and partially reacted quartz (dark grey) in left bottom and core with a few bright globules of copper metal in the middle; f) Location 11 (magnification 350x, width $250 \mu \mathrm{m}$ ). Note partially reacted quartz grains in a bright metal-speckled slag matrix; g) Location 8 (magnification 80x, width 1.4mm). Note slag matrix (light grey) with partially reacted quartz and bright phases suspended in it; h) Location 8 (magnification 400x, width $250 \mu \mathrm{m}$ ). Note bright spinel agglomerations and lathes of delafossite surrounded by partially reacted quartz and embedded in slag matrix. i) Location 9 (magnification 100x, width $1.2 \mathrm{~mm}$ ). Note bright globules of copper metal throughout the item, with partially reacted and unreacted quartz. 
Nevertheless, there are two locations in CHM 11 (location 5 and 11) where the copper metal appears as fully chemically and physically transformed (Figures $12 \mathrm{~d}, 12 \mathrm{e}, 12 \mathrm{j}, 13 \mathrm{a}, 13 \mathrm{~b}$ ), forming pools of liquid metal in a glassy slag matrix speckled with dark red patches of copper oxide. In location 8 (Figures 12h, 12i, 13h), the slag matrix formed two distinctive phases: straight lathes of delafossite and convoluted agglomerations of iron-rich oxides (see below for analyses).

Significantly, the position of the molten phases/slag in the observed items is predominantly at their edges, not their cores (Figures 12d, 12e, 13a). The cores are, almost by rule, populated with specks and agglomerates of metallic copper (not molten throughout), quartz grains and an unreacted copper-oxide rich matrix (e.g. Figures 12c, 13g, 13g, 13i). Neuninger et al. (1964: 100) also noticed this and characterised the studied item (probably only loc. 5 here) as a 'combination of a porous molten material with natural mineral structure'. Such position and morphology of these fully liquefied phases in locations 5, 8 and 11 is telling of a high-temperature impact and reducing conditions that took place on the outer surface of some fragments in CHM 11, but failed to reach throughout the material. Given that these patches of fully liquefied phases represent 'true' slag, we will give a more detailed analytical account of these areas below. The mostly unreacted ('cold') core in the majority of observed items is the evidence of this thermal impact not reaching sufficiently high temperatures long enough to transform them into a fully liquefied (slag and metal) mass, like the one observed on the edges of three out of fifteen locations in sample CHM 11.

\section{Bulk composition of the slag matrix}

The slag in locations 5, 8 and 11 is heterogeneous, containing metal prills and partially reacted quartz in locations 5 and 11, and delafossite instead of metal prills in location 8, all present to different extents and embedded in a matrix of crystallised slag glass (Figures 12, 13). All locations are dominated by a significant copper (oxide) content. The bulk chemical analyses of the 'true' slag portions of these locations were conducted in areas relatively free from corrosion with the main aim of understanding their formation.

The bulk composition of slag in locations 5,8 and 11, including all primary phases, shows that major oxides (silica, alumina, iron and copper oxides) add up to c. $77 \mathrm{wt} \%$ on average. Lime, potash, magnesia and phosphorus oxide contribute c. $19 \mathrm{wt} \%$ mean sum, and ore contamination (zinc and lead oxides) amounting up to c. $7.3 \mathrm{wt} \%$ in location 5 (Table 7). Significant differences in the bulk slag composition, particularly in location 5, affect lime (c. $23 \mathrm{wt} \%$ mean), which is four to five times higher than in the other two locations. This might be an indication of either a higher fuel ash content, or lime coming from both ore and fuel contamination (see example in Radivojević and Rehren, 2016: 224, Fig. 11). The contamination from ore elements (zinc and lead oxides) is only present in this location, and is reflected also in the composition of the glassy slag matrix (Table 8).

Spot analyses of the glassy slag matrix were conducted in areas relatively free of copper-rich phases or residual quartz. The major oxide distribution is similar to the bulk analyses, despite the lower copper content (Table 8). 
The ore contamination is the most significant in location 5 (zinc and lead oxides at $7.5 \mathrm{wt} \%$ ). The silica to alumina ratio is $4: 1$ in both locations 8 and 11, while in location 5 it is around 15:1. This observation identifies locations 8 and 11 as those containing a metallurgical slag, while location 5 appears more affected by silica-rich fuel ash.

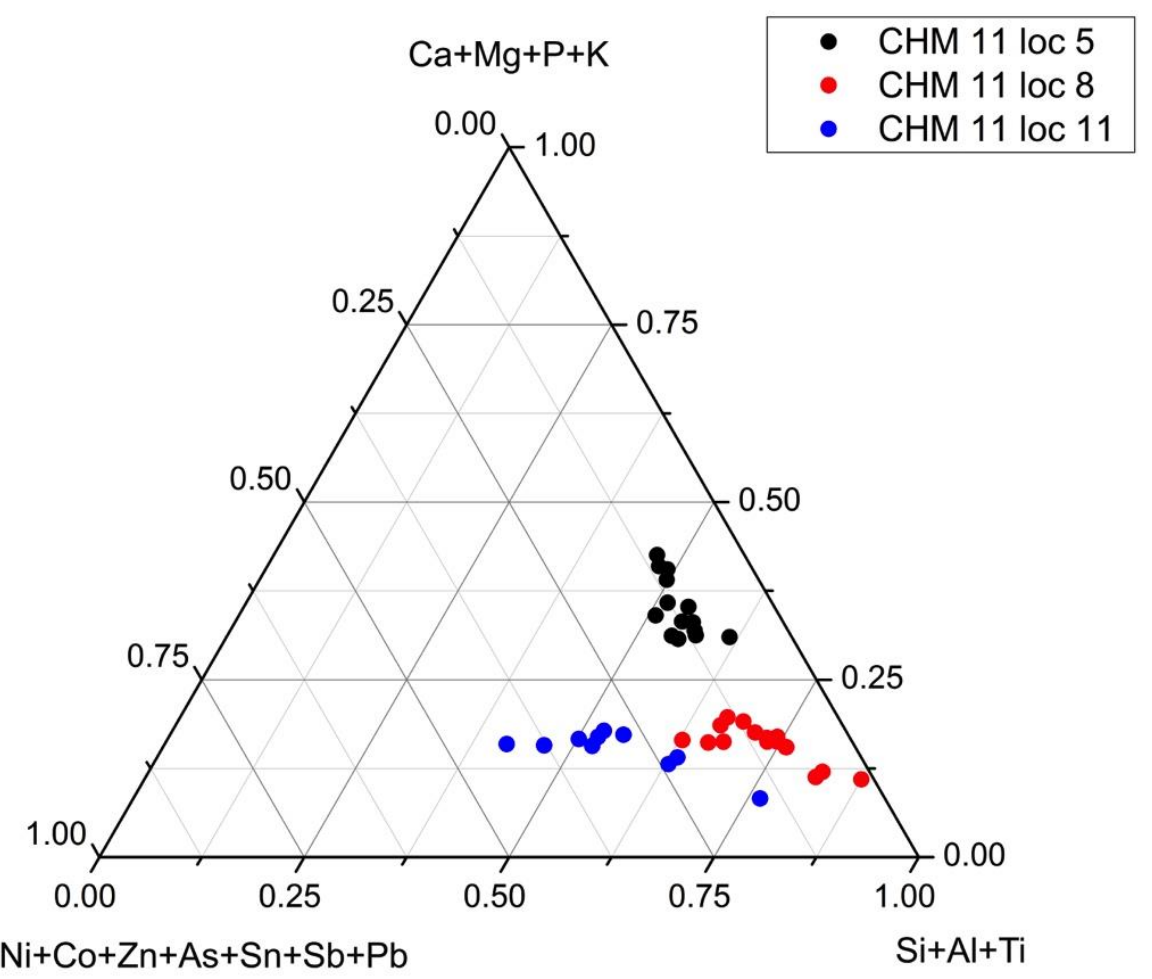

Figure 14: The ternary plot of compositional values of $\mathrm{Si} / \mathrm{Al} / \mathrm{Ti}-\mathrm{Ca} / \mathrm{Mg} / \mathrm{P} / \mathrm{K}-\mathrm{Fe} / \mathrm{Zn} / \mathrm{As} / \mathrm{Sb} / \mathrm{Pb}$ oxides in glassy slag matrices in CHM 11, locations 5, 8 and 11. All values re-cast as $\mathrm{Cu}$-free oxides.

The ternary plot (Fig. 14), representing all components influencing the formation of slag: ceramic/soil $\left(\mathrm{SiO}_{2} / \mathrm{Al}_{2} \mathrm{O}_{3} / \mathrm{TiO}_{2}\right)$, fuel ash $\left(\mathrm{CaO} / \mathrm{MgO} / \mathrm{P}_{2} \mathrm{O}_{5} / \mathrm{K}_{2} \mathrm{O}\right)$ and ore $\left(\mathrm{FeO} / \mathrm{ZnO} / \mathrm{As}_{2} \mathrm{O}_{3} / \mathrm{Sb}_{2} \mathrm{O}_{3} / \mathrm{PbO}\right)$, illustrates well the differences in the studied locations in sample CHM 11. The locations produce slightly distinctive patterns by their predominant formation by acidic oxides $\left(\mathrm{SiO}_{2} / \mathrm{Al}_{2} \mathrm{O}_{3} / \mathrm{TiO}_{2}\right.$ corner, location 8$)$, stronger intake of fuel component (location 5), or ore contamination (location 11), respectively.

Copper oxides are the dominant phase in all locations in CHM 11, as newly generated phases or as corrosion products. It is mostly found as a copper 'dross' outside the slag matrix, with traces of $\mathrm{Zn}$ and As. Tenorite was found in locations 3, 12 and 13 (Fig. 5), with only one measurement showing Zn (5 at\%, location 13) in addition to copper. These metal oxide-rich 'dross' areas, are indicative of copper melting events (Bachmann, 1982), although they also occur in very early examples of copper smelting, like in the Balkans (Radivojević et al., 2010; Radivojević and Rehren, 2016) or in Iberia (Müller et al., 2004). 
Delafossite, $\mathrm{Cu}^{1+} \mathrm{Fe}^{3+} \mathrm{O}_{2}$, is usually recognised optically as straight lathes embedded in the glassy matrix (Table 9, Figures 12i, 13h) and mixed with iron spinels in convoluted agglomerations embedded in the slag matrix. Its cooccurrence with cuprite in a sample indicates fairly oxidising conditions of the melt, bordering the partial oxygen pressure required to reduce copper from cuprite (Müller et al., 2004: 40). It forms both during melting and smelting (see Bachmann, 1982: 16 for melting; and Hauptmann et al., 1993: 566; Hauptmann, 2000: 147 for smelting examples).

Iron spinels form characteristic grey cubic crystals in the glassy matrix, corresponding to the general formula $\mathrm{A}^{2+} \mathrm{B}_{2}{ }^{3+} \mathrm{O}_{4}{ }^{2-}$. In both locations 11 and 15 , they are found intergrown with delafossite in convoluted agglomerations, containing copper in addition to predominant iron (Table 9), as well as impurities coming from the surrounding slag matrix.

Metal prills and particles are found both suspended in the slag matrix and freely forming in other 'cold' areas throughout different locations (see Figures 12, 13). SEM-EDS analyses revealed almost pure copper with occasional presence of Sb and S (at c. 1 at\%). LA-ICP-MS analyses (Table 10, Fig. 15) of the copper metal prills embedded in the peripheral slag matrix of location 5 showed the copper to contain $\mathrm{As}$, Sb and Ni, consistent with the copper composition being reduced from malachite with some admixture of mostly antimonial fahlore.

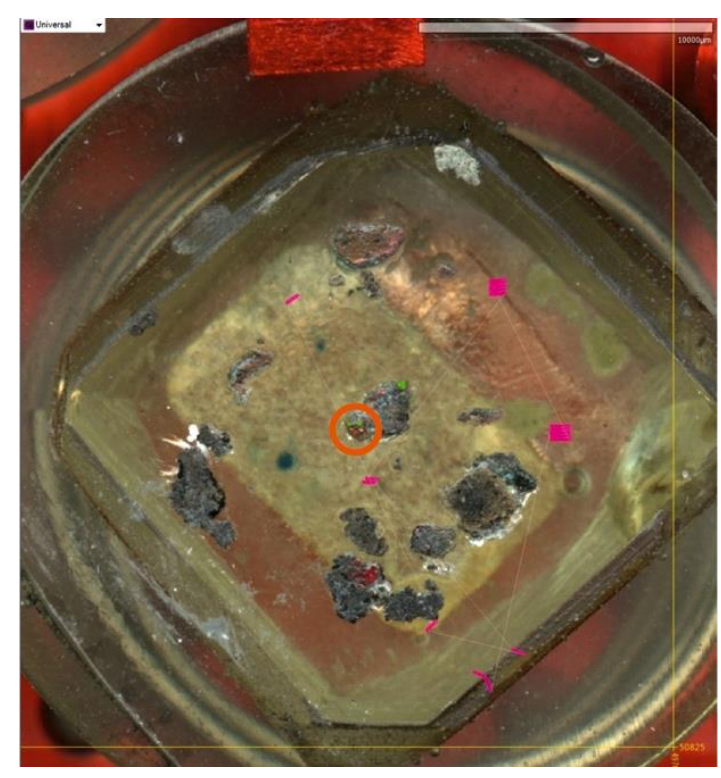

Figure 15: The orange circle indicates the location of copper metal phase analysed by LA-ICP-MS in sample CHM 11 (loc. 5) from Çatalhöyük.

Location 5 also includes optically pale metal prills that contain a eutectic of a light grey and a grey phase (Figures 12f, 12g, 13d). SEM-EDS analyses showed that they are antimonial copper (Table 11), with c. 25 at\% of Sb in both phases, and a significant intake of $\mathrm{Pb}$ in the latter (c. 15 at\% on average). This clearly reflects the original mineral, pointing at the tetrahedrite mineral series, similar to the phases observed in CHM 1, 5, 9 and 10 (Tables 
4-6). These pale metal prills formed outside the slag matrix, in the cold 'core' of the location 5, and are surrounded by metallic particles of copper, interpreted above as very likely produced in situ. It is therefore equally likely that the antimonial copper prills were created in the same way, under conditions long and hot enough to ensure the in situ metal reduction but not the thorough melting of slag and copper in this location. Antimonial copper of this composition melts at around $650{ }^{\circ} \mathrm{C}$, a temperature obviously exceeded in this spot as indicated by the prills' shape. The occurrence of such a compositionally distinctive phase only in location 5 in sample CHM 11 matches the compositional variability of the mineral fragments presented above, and further corroborates the assumption of it representing an incomplete in situ smelting event, not reaching conditions sufficient to homogenise the molten metal beyond across a fraction of a millimetre. Effectively, location 5 mirrors the diverse composition of a mineral association that included pure copper minerals as well as antimonial fahlore, similar to that already seen in the copper minerals from the same archaeological context of grave 5, building E.VI.1 (CHM 9, 10 and 12) and other contemporary buildings in Level VI.

\subsection{Metal beads}

We re-cast the existing blocks of the metal beads CHM 14, 15, 30, 34 and 35. These represent individual metal artefacts, barring CHM 15, which consists of four locations (2-5) (Fig. 6). CHM 13 and 16 (a metal bead from each assemblage) were analysed for their lead isotope ratios only.

All beads were heavily corroded with little if any metal left. The surviving structure showed that they were worked into their shape by hammering, as seen in the orientation of (corroded) grains, e.g. in CHM 14, 15 (loc. 3 ), 30,34 and 35 (Figures 16a, 16d, 16g, 16h and 16i). Metal bead CHM 34 in particular preserved the elongated direction of grains in the corroded metallic structure, thus indicating the heavy hammering work conducted on it (Fig. 16h). A metal bead in CHM 15 (location 2, Figures 16b, 16c) has annealing twins in the preserved copper metal, indicating that the last working step for this artefact was heating above the recrystallization temperature for copper to soften the metal. Thus, the beads were made in a sequence of steps already recognised for copper beads from this site (Neuninger et al., 1964; Birch et al., 2013), and in Anatolia in general, from as early as the $8^{\text {th }}$ mill cal BC (e.g. Stech, 1990; Yalçın and Pernicka, 1999; Özdoğan and Özdoğan, 1999; Maddin et al., 1999). To produce these beads, native copper was hammered into sheet, divided into strips, rolled and cut, and subsequently worked and annealed. Although we were able to positively recognise this only in sample CHM 15 (loc. 2), we are confident in the light of the regional and contemporary evidence that this working procedure was applied to all copper artefacts from the site of Çatalhöyük, too.

LA-ICP-MS analysis of the metal phases in CHM 15 (locations 2 and 3) revealed pure copper metal, with very low concentrations of trace elements (Table 10, Fig. 17). From the pattern of the trace elements with silver and arsenic as the only elements that could be quantified (except for silicon, certainly part of the host rock), it can safely be concluded that this bead was made of native copper. 

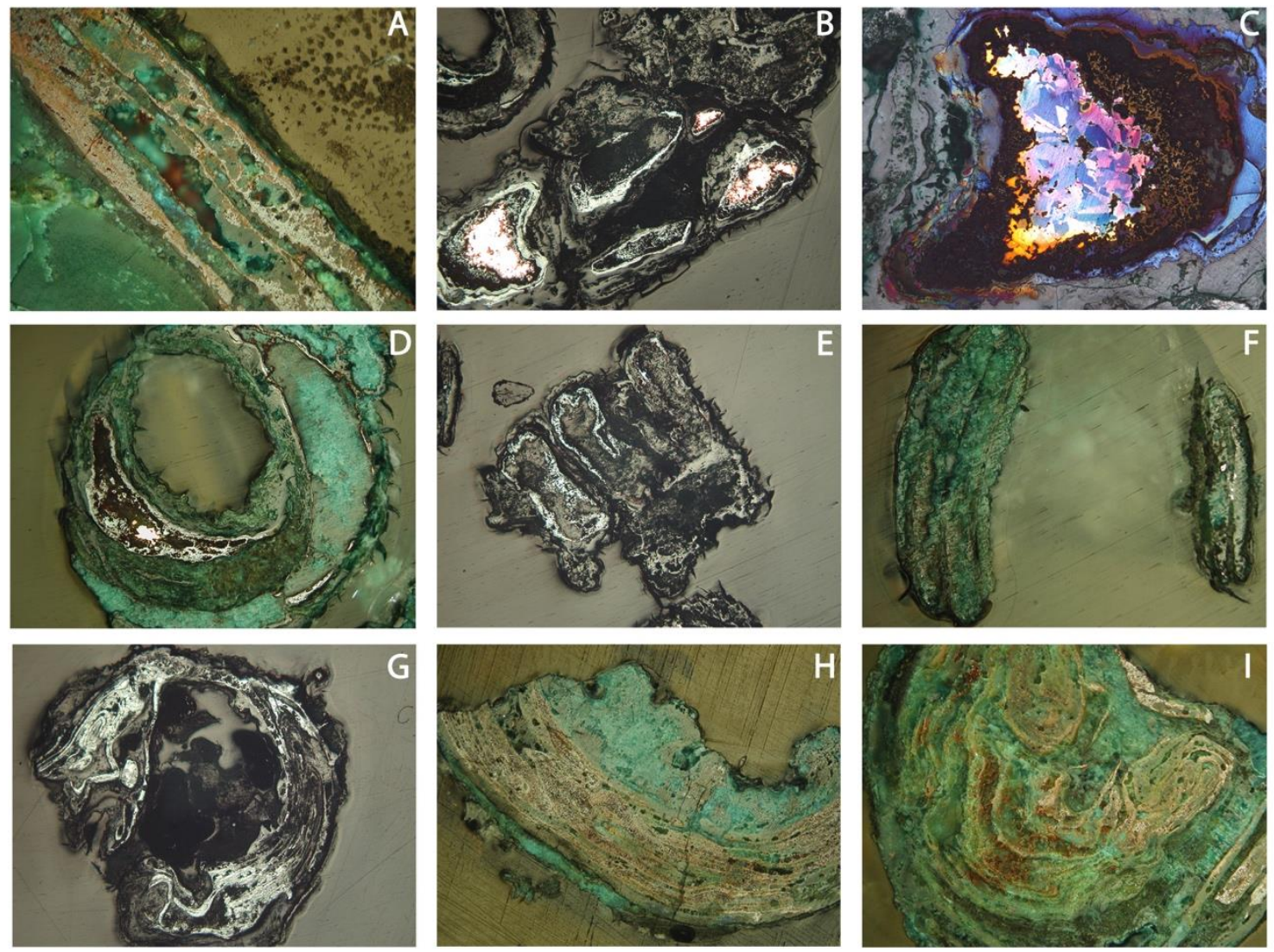

Figure 16: Photomicrographs of metal beads from Çatalhöyük taken under both plain (ppl) and cross polarised light (xpl). a) Photomicrograph of CHM 14 (magnification 100x, width $1 \mathrm{~mm}$, xpl). Note green corrosion inside a porous copper metal sheet; b) Photomicrograph of CHM 15, location 2 (magnification 25x, width 6.4mm, ppl). Note still preserved shiny copper metal amongst corrosion layers that outline a minimum of four structures/objects welded together due to post-depositional processes; c) Photomicrograph of CHM 15, location 2 (magnification 200x, width 0.6 $\mathrm{mm}, \mathrm{ppl})$. Note the 'natural' etching effect coming out of an extensive polishing. The grain structure shows evidence of working/hammering and annealing; d) Photomicrograph of CHM 15, location 3 (magnification 50x, width 3.2mm, xpl). Note the shiny copper metal and the outlines of corrosion products revealing the circular shape of a metallic bead; e) Photomicrograph of CHM 15, location 4 (magnification 25x, width 6.4mm, ppl). Note at least three structures/objects that corroded together; f) Photomicrograph of CHM 15, location 5 (magnification 50x, width $3.2 \mathrm{~mm}, \mathrm{xpl})$. Note the outline of a circular bead with several preserved spots of copper metal amongst corrosion products; g) Photomicrograph of CHM 30 (magnification 25x, width 6.4mm, ppl). Note the circular shape of a bead made out of corrosion only; h) Photomicrograph of CHM 34 (magnification 50x, width 3.2mm, xpl), Note a shape of a fragmented metal bead outlined with a corrosion product. The metallic part (in the middle) retained still visible shape of elongated grains in its structure, a result of an intensive hammering work conducted in order to gain a desired shape of this object; i) Photomicrograph of CHM 35 (magnification 50x, width 3.2mm, xpl). Note a thick-walled metallic bead with corrosion layers growing out of folding lines (see top right for this detail).

Metal beads CHM 13 and CHM 15 were studied for provenance with lead isotope analyses (Table 12). A comparison of the lead isotope ratios of the two samples with the available data of copper ores in Turkey (Seeliger et al., 1985; Wagner et al., 1986; Wagner et al., 1989; Yener et al., 1991; Begemann et al., 2003, and unpublished 
data from Curt-Engelhorn-Zentrum Archäometrie, Mannheim) finds the closest parallels in northeastern Turkey at Murgul and Gümüshane in the Artvin province (Fig. 18). There is also one sample from Ikiztepe near Kirklareli in Turkish Thrace (Fig. 19) that seems to match but this is a rather unlikely provenance. However, when taking into account ${ }^{204} \mathrm{~Pb}$ in the denominator (Fig. 20), it is clear that no complete match is to be found in the available data. In this diagram the closest sample is from Esendegirmentepe in the Nigde province (Yener et al., 1991), which would also be geographically closest to Çatalhöyük, however, since other lead isotope ratios of these beads do not show consistency with this location, we must exclude it as a possible source. In summary, the geological origin of the studied samples remains unknown at this point.

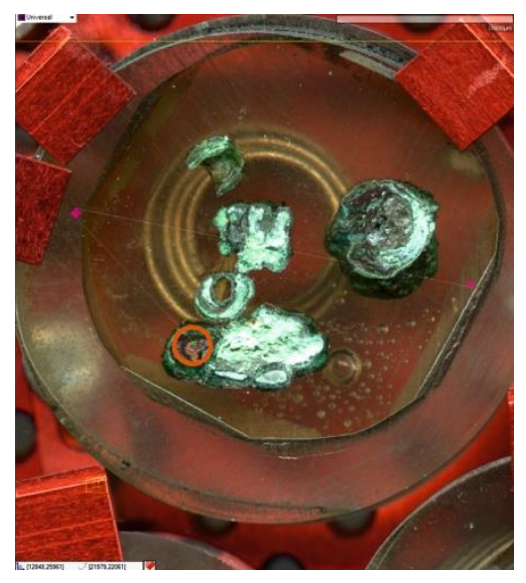

Figure 17: The orange circle indicates the location of copper metal phase analysed by LA-ICP-MS in sample CHM 15 from Çatalhöyüik.

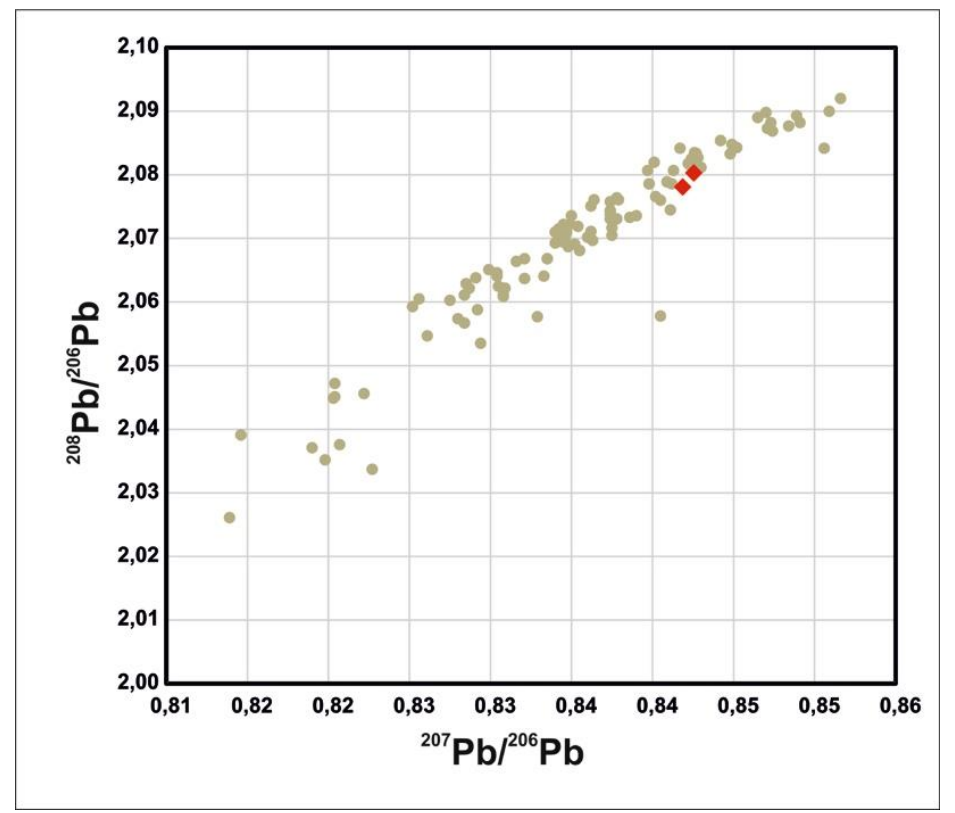

Figure 18: Overview lead isotope ratios of copper ore samples from Turkey compared with samples CHM 13 and CHM 16 from Çatalhöyük in red. 


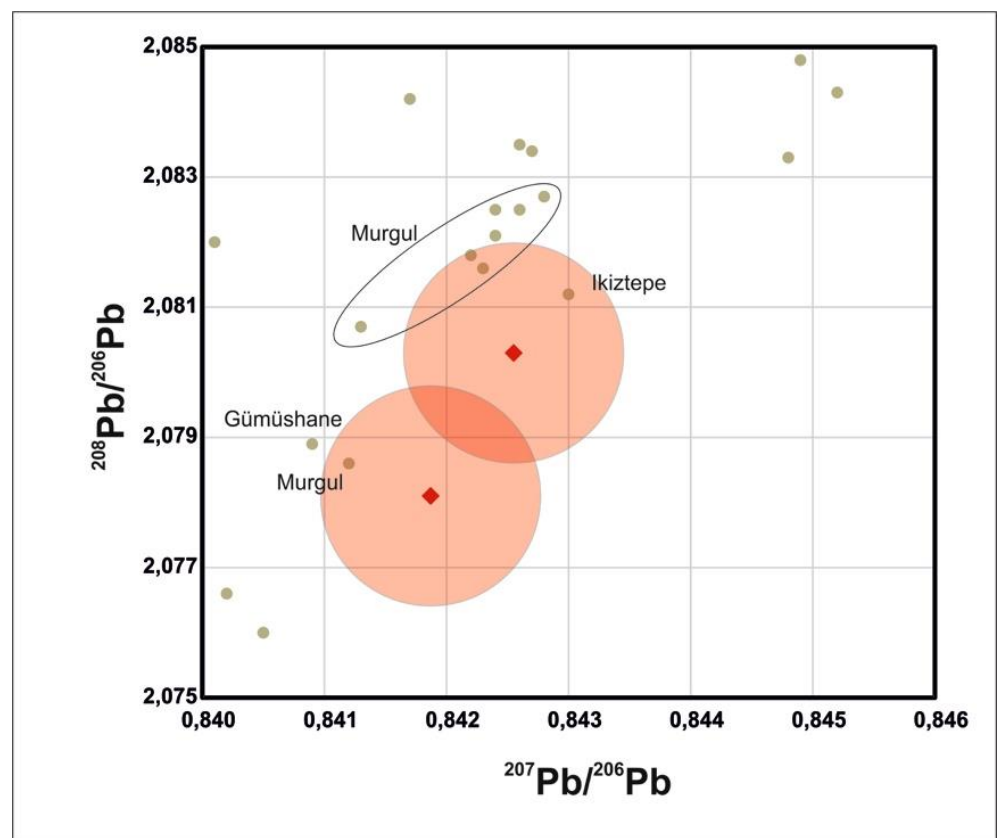

Figure 19: Detailed comparison of Turkish copper ores with the two samples CHM 13 and CHM 16 from Çatalhöyük in red. The red halos comprise data within $0.1 \%$ of the copper samples. No consistency has been found with the available dataset.

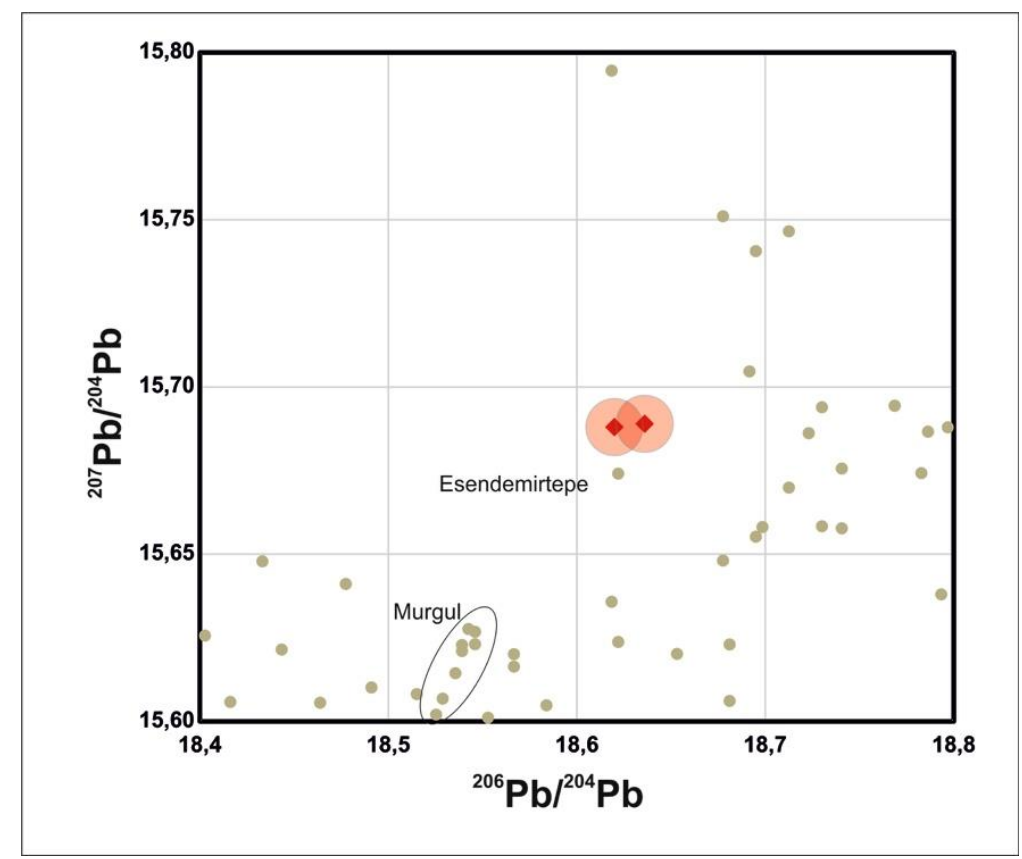

Figure 20: Alternative diagram for the detailed comparison of Turkish copper ore with the two samples CHM 13 and CHM 16 from Çatalhöyük (in red). The red halos comprise data within $0.1 \%$ of the copper samples. No consistency has been found with the available dataset. 


\section{Discussion}

The analyses above identify two distinctive groups of materials in the studied assemblage from Çatalhöyük: copper minerals and the 'slag' samples form one related category of materials, while copper metal beads make another.

The underlying criterion that links the copper minerals with a 'slag' in the same group is the distinctive chemical signature dominated by copper, and also containing zinc, lead, antimony and arsenic. These elements were found in mineral-based samples CHM 1, 5, 9, and 10 (in various ratios), as well as in the glassy slag matrix and some metal prills in CHM 11. Although different minerals were identified in the samples, it is important to emphasise their close geological relationship in nature. Broadly speaking, they probably originate from a weathered hydrothermal copper deposit with lead and zinc-bearing sulfidic minerals including the tennantite and tetrahedrite series, like (antimony-bearing) enargite and other fahlore-type minerals. Specimens from such a deposit would also be aesthetically appealing, with a colour palette dominated by different shades of green (for instance from malachite), including shades from pale/yellow to metallic grey or black. Noteworthy in this context is the crumbly nature of studied minerals, which macroscopically finds parallel with the hand-crushed pigments deposited in a few Çatalhöyük burials (see Fig. 2).
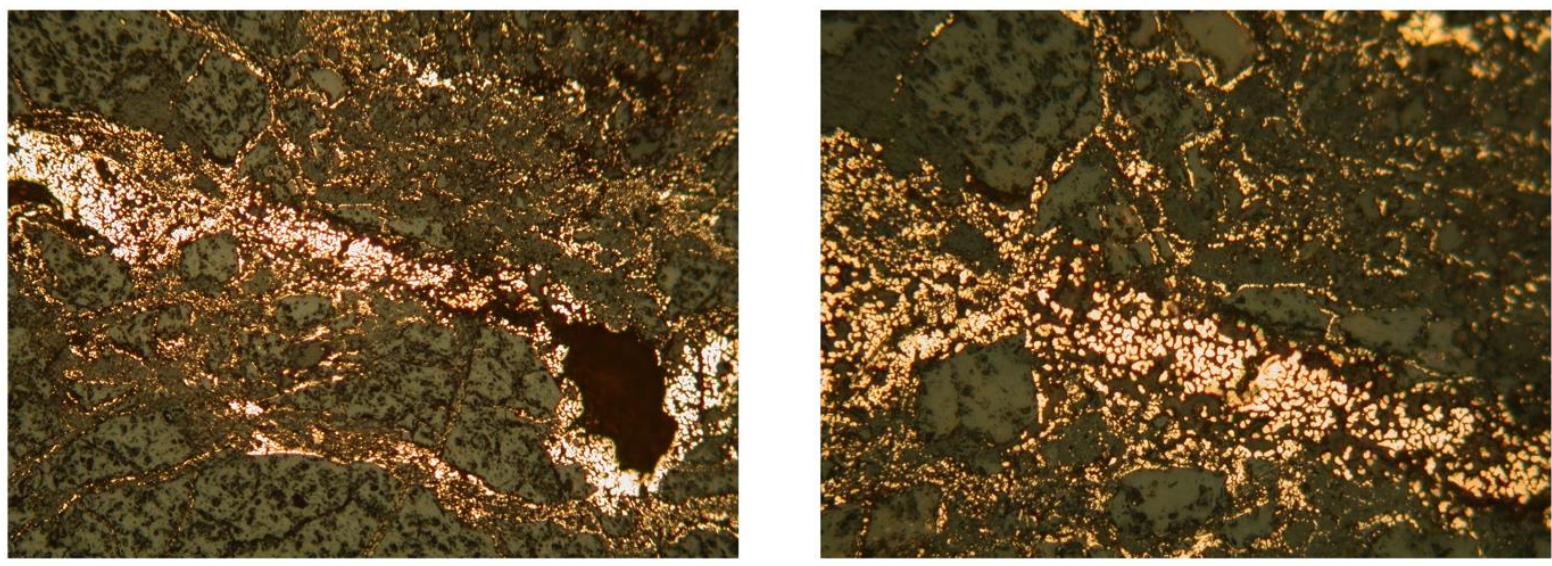

Figure 21: Photomicrographs of experimentally produced metallic globules 'in situ', in an hour long experiment in Serbia in 2013, taken under the plain polarised light (left: magnification 100x, width 1mm; right: magnification 200x, width $0.5 \mathrm{~mm}$ ). Note similarity with Figures $13 \mathrm{c}$ or $13 f$.

\subsection{CHM 11: Metallurgical slag?}

This combination of elements closely links the mineral samples to the only 'slag' sample in the studied collection, CHM 11. It consists of finely scattered copper particles with discrete prills of a metal phase rich in antimonial copper in location 5 (Table 11, Figures 12f, 12g). Its morphology and immediate surrounding appear as formed 
'in situ' in an environment that did not reach full liquefaction, thus preventing a merging of the individual metal particles to a few larger prills. As an illustration to the 'in situ' solid state production of metallic copper, preserving the original outline of the copper mineral despite its reduction to copper metal, we show in Fig. 21 results from a copper smelting experiment conducted by the first author in Serbia in 2013. The slag produced after a short-lived thermal impact shows an incompletely liquefied area populated by small copper particles that transformed chemically from the initial copper oxide, but failed to amalgamate into larger prills. The principle of such solidstate metal reduction without producing a molten metal phase is well known from bloomery iron smelting, which produces very similar structures.

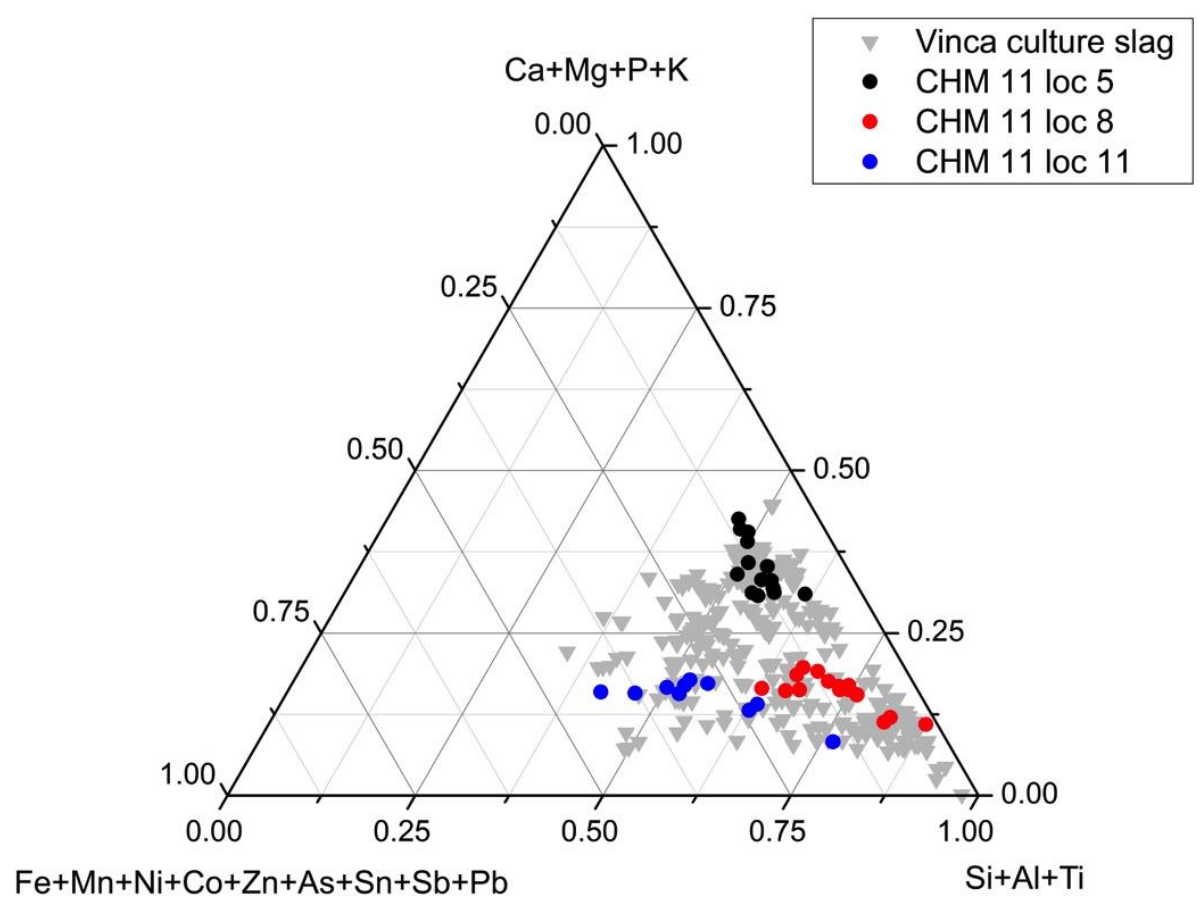

Figure 22: The ternary plot of compositional values of $\mathrm{Si} / \mathrm{Al} / \mathrm{Ti}-\mathrm{Ca} / \mathrm{Mg} / \mathrm{P} / \mathrm{K}-\mathrm{Fe} / \mathrm{Zn} / \mathrm{As} / \mathrm{Sb} / \mathrm{Pb}$ oxides in glassy slag matrices in CHM 11, locations 5, 8 and 11, plotted against values from the Vinča culture slags from the sites of Belovode, Vinča and Gornja Tuzla in Serbia and Bosnia and Herzegovina (data from Radivojević et al. 2010; Radivojević 2012; Radivojević 2015; Radivojević and Rehren 2016). All values re-cast as Cu-free oxides.

Metallic particles of copper that possibly formed below melting temperature (cf. Pollard et al., 1991) are common throughout all locations in CHM 11, more often embedded in baked soils rather than proper slag. Islands of glassy slag matrix formed at the outskirts of only three out of fifteen locations within CHM 11, consisting of a 'true' slag phase with fully molten (antimonial) copper prills and newly-formed crystals of cuprite, delafossite and iron spinels. Their paragenesis in a slag matrix illustrates variable, and slightly reducing conditions, sufficient to smelt copper (cf. Elliott, 1976). However, despite the formal conditions for smelting being met, it is difficult to identify intentionality in this pattern. Another indicator of a haphazard nature of exposure of different locations in CHM 11 to high temperatures is the slags' diverse compositional patterns (Fig. 14). The three locations with slag matrix 
in their outskirts differ considerably in their intake of the three major components in slag formation: minerals, fuel ash, and ceramic/soil.

The compositional values extracted from these 'islands' of glassy slag matrices are corresponding well to the values obtained from c. 7000 years old metallurgical slag samples from three different Vinča culture sites in Serbia (Fig. 22), with which they also share common phase associations and textures (Radivojević et al., 2010; Radivojević, 2012; Radivojević and Rehren, 2016: 215 ff., Fig. 6). In effect, this ternary plot confirms that the glassy slag areas from CHM 11 are indeed similar to the earliest known metal smelting evidence to date.

However, the context of the observed glassy matrices in Çatalhöyük's CHM 11 and Vinča slag samples highlights important differences: while the Vinča slags, despite being highly viscous and heterogeneous, are liquefied throughout (Radivojević and Rehren, 2016), the slag in CHM 11 is a peripheral formation to a core that has not been exposed to the ash of some organic material near-by which acted as a flux to produce a liquid slag on the surface of some fragments. The haphazard nature of the slag phase formation in CHM 11 underlines the accidental nature of these three out of fifteen locations in the mentioned sample (Fig. 5). Their overall heterogeneous nature is a result of a compositional rather than a thermal gradient, even though the vitrification is predominantly on the surface of the fragments as if they were affected by a short direct exposure to fire. Compositional heterogeneity is a normal feature of a fine-grained rock or a powder with a mixture of minerals which on its surface was fluxed by ash, while the temperature would have been the same across such a small sample with minute size inclusions as in sample CHM 11 which was slowly baked as part of a burial affected by a major conflagration above it.

In addition, the solid-state formation of metallic copper particles alongside similarly shaped antimonial copper in location 5 in CHM 11 illustrates the reduction of a mineral association that contained both pure copper minerals and a fahlore-type mineral, as seen in the copper mineral fragments (CHM 9, 10 and 12) from the same context. Thus, any artefacts made from metal smelted from such a mixed ore would inevitably contain noticeable concentrations of elements such as antimony or lead naturally present in the green-grey minerals, but none of these have been found in any of the analysed copper metal artefacts from Çatalhöyük. Instead, their composition, as determined by LA-ICPMS, matches that of native copper (see also Birch et al. 2013), indicating that the demand for metallic copper was met by sources of the native metal, and not through smelting of copper ores.

We were unable to find evidence of an intentional smelting event at the site of Çatalhöyük directed towards extracting copper metal for further use. Therefore, we propose here that the 'slag' sample CHM 11 was produced accidentally, most likely when a collection of minerals was caught up in a fire event in building E.VI.1, earlier reported by Mellaart (1964: 85) as carbonizing skeletons and burial goods buried up to 3 feet (c. $90 \mathrm{~cm}$ ) deep. Hence, the 'slag' sample (CHM 11) is best termed as a partially vitrified mixture of minerals and soil, which happened to be the most heat-exposed specimen in the contextually associated collection of samples (CHM 9-12). 
Considering the nature of their context and the miniature size of the studied 'locations', it appears very likely that these samples were originally deposited in the burial (Grave 5 from the central platform) as hand-crushed green or blue minerals, and then burned in a post-depositional fire. This matches the documented contexts of burial deposition of green (malachite) or blue (azurite) pigments that Mellaart reported (1964) as paint (on a skull) or as free lumps; similar finds originate from funerary contexts in the renewed excavations, too (Thornton, 2001). Çamurcuoğlu (2015) documented powdered malachite and azurite pigments coated with clay and iron oxide particles, which match closely what we see in Figures 2, 9 and 10, although our samples appear more finely dispersed in soil. Although green stones were used for artefact (bead) making in Çatalhöyük, it is important to emphasise that those stones were not malachite, but apatite, or similarly green-coloured minerals, in line with the argument that green colour was more important than the mineral type (e.g. Bar-Yosef Mayer and Porat, 2008). However, malachite was used at Çatalhöyük as a pigment in burial contexts, on which we base our interpretation for the nature of CHM $9-12$ samples studied here.

The copper metal beads analytically stand in stark contrast to all studied minerals, including the vitrified mineral CHM 11. The beads are all consistent with being made of native copper, clearly distinguishing them from the lightly antimonial copper seen in CHM 11. The composition and technology of working of these pure metal samples corresponds well with contemporary finds across Anatolia, while their provenance remains unknown.

\section{Conclusions}

For nearly half a century, Çatalhöyük has played a major role in the discussion of the inception of metallurgy, based primarily on the frequent reference Mellaart made to the occurrence of metal finds in layers as early as the 7th millennium cal BC, and the identification by Neuninger et al. (1964) of metallurgical slag in one of the samples they analysed. Careful reconciliation of the surviving documentation from Mellaart's excavations with the material record demonstrated beyond doubt that Mellaart used the word 'metal' in a very liberal sense, clearly including different minerals in that category. Unfortunately, the excavation records do not allow to pinpoint individual samples to specific contexts within individual houses to the level of detail one would expect today; however, Mellaart's enthusiasm to engage with scientific analysis at that time resulted in the survival and identification of this crucial and unique material. What remains particularly commendable is the great detail of excavation technique, which led to the recovery of miniature metallic samples from the soil, as exemplified in Fig. 5.

Detailed re-analysis of the CHM 9 -12 samples sent to Neuninger in the 1960s proved beyond doubt that only sample CHM 11 showed the formation of metallic copper from minerals, which prompted Neuninger et al. (1964) to define it as 'metallurgical slag'. Indeed, three out of 15 fragments within sample CHM 11 closely match the chemical and microstructural features known from very early smelting slag elsewhere (Bachmann, 1980; Müller 
et al., 2004; Höppner et al., 2005; Bourgarit, 2007; Radivojević et al., 2010; Radivojević, 2013), including the formation of small prills of antimonial copper and of a range of copper and iron oxides in a semi-molten and compositionally heterogeneous siliceous matrix. The remaining fragments are rich in finely dispersed copper particles apparently reduced in the solid state from some secondary copper minerals, whose outer shape they sometimes retain, without agglomerating into prills.

In the light of the analytical and contextual evidence, we interpret this material as the result of accidental copper reduction when some crushed green minerals in a burial context were baked in a post-depositional fire in dwelling E.VI.1 in Çatalhöyük, whose thermal effect reached not only these minerals/pigments, but also the bodies and burial items to a depth of at least $90 \mathrm{~cm}$ (see Mellaart, 1964; Angel, 1971; Burnham, 1965). These crushed green minerals might have been sprinkled over the body, or deposited in a pouch that decayed over time; the result of both processes would have been loose green mineral fragments (pigments?) scattered around the human remains. The accidental result of this event was the solid-state reduction of metallic (antimonial) copper and formation of peripheral copper slag in some of the surviving fragments. This process would have taken place in mildly reducing conditions created by the burning or charring of some organic matter in the burial; the ash of this would have led to the superficial vitrification ('slagging') of some of the mineral-rich particles.

Taken together, the evidence from Mellaart's 'metal' samples therefore is consistent with our understanding of the selection and different treatment of green minerals and native copper during the $7^{\text {th }}$ millennium $\mathrm{BC}$ in Anatolia and surrounding regions, rooted in earlier practice and continuing for another couple millennia. A link from this material to the inception of metallurgy, however, has been finally put to rest, effectively removing from the discussion the already much-damaged this 'Exhibit \#1' for a single origin of metallurgy. Conversely, this leaves intact the notion of probably independent origins of metallurgy in the Balkans and possibly Iran c. 1500 years later, at the turn of the $6^{\text {th }}$ to the $5^{\text {th }}$ millennium BC. It is beyond the remit of this paper to explore the socioeconomic and technical conditions leading to this broadly synchronous emergence of metallurgy in geographically widely separated regions. However, accepting multiple origins of metallurgy enables us to advance the focus of our research onto those parameters, which these progenitor cultures and metalliferous regions share, in order to identify the essential conditions leading to the invention and innovation of the controlled smelting of metal.

\section{Authors' contributions}

MR and ThR conceived, designed and coordinated the study and interpreted all data; SF and MR collected and interpreted contextual data; MR and EP carried out all analytical work and data processing; DC conducted pigments analysis; MR, ThR, SF and EP drafted the manuscript. All authors gave final approval for publication. 


\section{Acknowledgements}

We owe a great debt of gratitude to Professor Gerhard Sperl for giving us full access to the material originally sent by Mellaart to Neuninger for analysis, and for providing all relevant documentation in his possession. This would not have been made possible without the generous support of Professor Ian Hodder. Much of the work was done while MR and SF were visiting researchers at UCL Qatar. Ana Franjić kindly re-polished the analysed material and Ljiljana Radivojević and Cordelia Hall prepared illustrations for publication. We are very grateful to Alex Bayliss for the interim statement, attached in the Supplementary Materials, on the chronology of Çatalhöyük. Qatar Foundation enabled the new study of this material through its generous funding of UCL Qatar as a joint centre of excellence for Museology, Conservation and Archaeology.

\section{Bibliography}

Angel, J. L. 1971. Early Neolithic skeletons from Çatal Höyük: demography and pathology. Anatolian Studies, 21, pp. 77-98.

Bachmann, H.-G. 1982. The Identification of Slags from Archaeological Sites, London: Institute of Archaeology.

Bachmann, H. G. 1980. Early copper smelting techniques in Sinai and in the Negev as deduced from slag investigations. In: Craddock, P. T. (ed.) Scientific Studies in Early Mining and Extractive Metallurgy. London: British Museum, pp. 103-134.

Bar-Yosef Mayer, D. E. \& Porat, N. 2008. Green stone beads at the dawn of agriculture. Proceedings of the National Academy of Sciences, 105, pp. 8548-8551.

Bayliss, A., Brock, F., Farid, S., Hodder, I., Southon, J. \& Taylor, R. E. 2015. Getting to the Bottom of It All: A Bayesian Approach to Dating the Start of Çatalhöyük. Journal of World Prehistory, 28, pp. 1-26.

Begemann, F., Schmitt-Strecker, S. \& Pernicka, E. 2003. On the composition and provenance of metal finds from Beşiktepe (Troia). In: Wagner, A., Pernicka, E. \& Uerpmann, H.-P. (eds.) Troia and the Troad: Scientific Approaches. Berlin, Heidelberg: Springer-Verlag, pp. 173-201.

Bialor, P. A. 1962. The chipped stone industry of Çatal Höyük. Anatolian Studies, 12, pp. 67-110.

Birch, T., Rehren, Th. \& Pernicka, E. 2013. The Metallic Finds from Çatalhöyük: A Review and Preliminary New Work. In: Hodder, I. (ed.) Substantive Technologies at Çatalhöyük. London, Los Angeles: British Institute at Ankara, Cotsen Institute of Archaeology, pp. 307-316.

Bourgarit, D. 2007. Chalcolithic copper smelting. In: La Niece, S., Hook, D. \& Craddock, P. (eds.) Metals and Mines: Studies in Archaeometallurgy. London: Archetype Publications, pp. 3-14.

Burnham, H. 1965. Çatal Höyük - the textiles and twine fabrics. Anatolian Studies, 15, pp. 169-174.

Camurcuoğlu, D. S. 2015. The Wall Paintings of Catalhoyuk (Turkey): Materials, Technologies and Artists. Unpublished PhD thesis. University College London 
Cessford, C. 2005. Absolute dating at Çatal Höyük. In: Hodder, I. (ed.) Changing Materialities at Çatalhöyük: reports from the 1995-99 seasons. Cambridge: McDonald Institute Monographs, British Institute at Ankara, pp. 65-100.

Cessford, C. \& Near, J. 2005. Fire, burning and pyrotechnology at Çatalhöyük In: Hodder, I. (ed.) Çatalhöyük perspectives: themes from the 1995-99 seasons. Cambridge, London: McDonald Institute Monographs, British Institute of Archaeology at Ankara Monograph, pp. 171-182.

Craddock, P. T. 2001. From hearth to furnace: evidences for the earliest metal smelting technologies in the eastern Mediterranean. Paléorient, 26, pp. 151-156.

Dana, E. S. \& Ford, W. E. 1922. A Textbook of Mineralogy (with an extended treatise on crystallography and physical mineralogy), New York: John Wiley and Sons.

Dougherty, R. C. \& Caldwell, J. R. 1966. Evidence of Early Pyrometallurgy in the Kerman Range in Iran. Science, 153, pp. 984-985.

Elliott, J. F. 1976. Phase relationships in the pyrometallurgy of copper. Metallurgical and Materials Transactions B. Process Metallurgy and Materials Processing Science, 7, pp. 17-33.

Farid, S. 2007. Level VII. In: Hodder, I. (ed.) Excavating Çatalhöyük: South, North and KOPAL Area reports from the 1995-99 seasons. Cambridge, London: McDonald Institute Monographs, British Institute of Archaeology at Ankara Monograph, pp. 283-338.

Frame, L. D. 2012. Reconstructing ancient technologies: Chalcolithic crucible smelting at Tal-i Iblis, Iran. In: Jett, P., McCarthy, B. \& Douglas, J. G. (eds.) Scientific Research on Ancient Asian Metallurgy. Proceedings ofthe Fifth Forbes Symposium at the Freer Gallery of Art. Washington, D. C.: Archetype Publications in association with the Freer Gallery of Art, Smithsonian Institution, pp. 183-204.

Glumac, P. \& Tringham, R. E. 1990. The Exploitation of Copper Minerals. In: Tringham, R. E. \& Krstić, D. (eds.) Selevac, A Neolithic Village in Yugoslavia. Los Angeles: University of California Press, pp. 549563.

Golden, J. M. 2010. Dawn of the Metal Age: Technology and Society during the Levantine Chalcolithic London, Oakville, CT Equinox Pub.

Harrison, K., Martin, V. \& Webster, B. 2013. Structural fires at Çatalhöyük In: Hodder, I. (ed.) Substantive Technologies at Çatalhöyük: Reports from the 2000-2008 Seasons. London, Los Angeles: British Institute of Archaeology at Ankara Monograph, Cotsen Institute of Archaeology Press, pp. 137-146.

Hauptmann, A. 2000. Zur frühen Metallurgie des Kupfers in Fenan/Jordanien, Der Anschnitt, Beiheft 11, Bochum: Deutsches Bergbau-Museum.

Hauptmann, A., Lutz, J., Pernicka, E. \& Yalçin, Ü. 1993. Zur Technologie der frühesten Kupferverhüttung im östlichen Mittelmeerraum. In: Frangipane, M., Hauptmann, A., Liverani, M., Matthiae, P. \& Mellink, M. (eds.) Between the Rivers and over the Mountains: Archaeologica Anatolica et Mesopotamica Alba 
Palmieri Dedicata. Roma: Dipartimento di Scienze Storiche Archeologiche e Antropologiche dell'Antichità, Università di Roma 'La Sapienza', pp. 541-563.

Helbaek, H. 1963. Textiles from Çatal Hüyük. Archaeology, 16, pp. 39-46.

Helwing, B. 2013. Early metallurgy in Iran - an innovative region as seen from the inside. In: Burmeister, S., Hansen, S., Kunst, M. \& Muller-Scheessel, N. (eds.) Metal Matters: Innovative Technologies and Social Change in Prehistory and Antiquity. Rahden/Westf.: Verlag Marie Leidorf, pp. 105-135.

Höppner, B., Bartelheim, M., Huijsmans, M., Krauss, R., Martinek, K. P., Pernicka, E. \& Schwab, R. 2005. Prehistoric copper production in the Inn Valley (Austria), and the earliest copper in central Europe. Archaeometry, 47, pp. 293-315.

Kavtaradze, G. L. 1999. The importance of metallurgical data for the formation of Central Transcaucasian chronology. In: Hauptmann, A., Pernicka, E., Rehren, Th. \& Yalçın, Ü. (eds.) The Beginnings of Metallurgy, Der Anschnitt, Beiheft 9. Bochum: Deutsches Bergbau-Museum, pp. 67-102.

Kenoyer, J. M. \& Miller, M.-L. 1999. Metal technologies of the Indus Valley tradition in Pakistan and western India. In: Pigott, V. C. (ed.) The Archaeometallurgy of the Asian Old World. Philadelphia (PA): University of Pennsylvania Museum, pp. 107-152.

Leusch, V., Pernicka, E. \& Armbruster, B. 2014. Chalcolithic gold from Varna - Provenance, circulation, processing, and function. In: Meller, H., Risch, R. \& Pernicka, E. (eds.) Metals of Power-Early Gold and Silver. 6th Archaeological Conference of Central Germany, October 17-19, 2013, Halle. Halle: Landesamt für Denkmalpflege und Archäologie Sachsen-Anhalt/Landesmuseum für Vorgeschichte, pp. 165-182.

Maddin, R., Muhly, J. D. \& Stech, T. 1999. Early metalworking at Çayönü. In: Hauptmann, A., Pernicka, E., Rehren, Th. \& Yalçın, Ü. (eds.) The Beginnings of Metallurgy, Der Anschnitt, Beiheft 9. Bochum: Deutsches Bergbau-Museum, pp. 37-44.

Maddin, R., Stech, T. \& Muhly, J. D. 1991. Çayönü Tepesi. The Earliest Archaeological Metal Artefacts. In: Mohen, J.-P. \& Éluère, C. (eds.) Découverte du Métal Paris: Picard, pp. 375-386.

Marciniak, A., Barański, M. Z., Bayliss, A., Czerniak, L., Goslar, T., Southon, J. \& Taylor, R. E. 2015. Fragmenting Times: interpreting a Bayesian chronology for the late Neolithic occupation of Çatalhöyük East, Turkey. Antiquity, 89, pp. 154-176.

Mellaart, J. 1961. Early Cultures of the South Anatolian Plateau. Anatolian Studies, 11, pp. 159-184.

Mellaart, J. 1962. Excavations at Çatalhöyük: first preliminary report, 1961. Anatolian Studies, 12, pp. 41-65.

Mellaart, J. 1963. Excavations at Çatalhöyük, 1962: second preliminary report. Anatolian Studies, 13, pp. $43-$ 103.

Mellaart, J. 1964. Excavations at Çatalhöyük, 1963: third preliminary report Anatolian Studies, 14, pp. 39-119.

Mellaart, J. 1966. Excavations at Çatal Höyük, 1965: fourth preliminary report. Anatolian Studies, 16, pp. 65191. 
Mellaart, J. 1967. Çatalhöyük, A Neolithic Town in Anatolia, London: Thames and Hudson.

Mickel, A. 2016. Tracing Teams, Texts, and Topics: Applying Social Network Analysis to Understand Archaeological Knowledge Production at Çatalhöyük. Journal of Archaeological Method and Theory, 23, pp. 1095-1126.

Muhly, J. D. 1989. Çayönü Tepeşi and the beginnings of metallurgy in the Old World. In: Hauptmann, A., Pernicka, E. \& Wagner, G. A. (eds.) Old World Archaeometallurgy, Der Anschnitt, Beiheft 7. Bochum: Deutsches Bergbau-Museum, pp. 1-13.

Müller, R., Rehren, Th. \& Rovira, S. 2004. Almizaraque and the early copper metallurgy of southeast Spain: new data. Madrider Mitteilungen 45, pp. 33-56.

Murillo-Barroso, M. \& Montero-Ruíz, I. 2012. Copper ornaments in the Iberian Chalcolithic: technology versus social demand. Journal of Mediterranean Archaeology, 25, pp. 53-73.

Neuninger, H., Pittioni, R. \& Siegl, W. 1964. Frühkeramikzeitliche Kupfergewinnung in Anatolien. Archaeologia Austriaca, 35, pp. 98-110.

Özdoğan, M. \& Özdoğan, A. 1999. Archaeological evidence on the early metallurgy at Çayönü Tepeşi In: Hauptmann, A., Pernicka, E., Rehren, Th. \& Yalçın, Ü. (eds.) The Beginnings of Metallurgy, Der Anschnitt, Beiheft 9. Bochum: Deutsches Bergbau-Museum, pp. 13-22.

Pernicka, E. 1990. Gewinnung und Verbreitung der Metalle in prähistorischer Zeit. Jahrbuch des RömischGermanischen Zentralmuseums Mainz 37, pp. 21-129.

Pernicka, E., Begemann, F. \& Schmitt-Strecker, S. 1993. Eneolithic and Early Bronze Age copper artefacts from the Balkans and their relation to Serbian copper ores. Prähistorische Zeitschrift 68, pp. 1-54.

Pernicka, E., Begemann, F., Schmitt-Strecker, S., Todorova, H. \& Kuleff, I. 1997. Prehistoric copper in Bulgaria. Its composition and provenance. Eurasia Antiqua 3, pp. 41-180.

Pigott, V. C. 1999. The development of metal production on the Iranian Plateau: an archaeometallurgical perspective. In: Pigott, V. C. (ed.) The Archaeometallurgy of the Asian World. Philadelphia (PA): University of Pennsylvania Museum, pp. 73-106.

Pollard, A. M., Thomas, R. G., Ware, D. P. \& Williams, P. A. 1991. Experimental Smelting of Secondary Copper Minerals - Implications for Early Bronze-Age Metallurgy in Britain. In: Pernicka, E. \& Wagner, G. A. (eds.) Archaeometry '90: International Symposium in Archaeometry. Basel: Birkhäuser, pp. 127136.

Radivojević, M. 2007. Evidence for early copper smelting in Belovode, a Vinča culture settlement in Eastern Serbia. MSc Thesis, UCL Institute of Archaeology.

Radivojević, M. 2012. On the Origins of Metallurgy in Europe: Metal Production in the Vinča Culture. $\mathrm{PhD}$ Thesis, UCL Institute of Archaeology.

Radivojević, M. 2013. Archaeometallurgy of the Vinča culture: a case study of the site of Belovode in eastern Serbia. Journal of Historical Metallurgy, 47, pp. 13-32. 
Radivojević, M. 2015. Inventing metallurgy in western Eurasia: a look through the microscope lens. Cambridge Archaeological Journal, 25, pp. 321-338.

Radivojević, M. \& Kuzmanović-Cvetković, J. 2014. Copper minerals and archaeometallurgical materials from the Vinča culture sites of Belovode and Pločnik: overview of the evidence and new data. Starinar, 64, pp. 7-30.

Radivojević, M. \& Rehren, Th. 2016. Paint It Black: The Rise of Metallurgy in the Balkans. Journal of Archaeological Method and Theory, 23, pp. 200-237.

Radivojević, M., Rehren, Th., Kuzmanović-Cvetković, J., Jovanović, M. \& Northover, J. P. 2013. Tainted ores and the rise of tin bronze metallurgy, c. 6500 years ago. Antiquity, 87, pp. 1030-1045.

Radivojević, M., Rehren, Th., Pernicka, E., Šljivar, D., Brauns, M. \& Borić, D. 2010. On the origins of extractive metallurgy: new evidence from Europe. Journal of Archaeological Science, 37, pp. 27752787.

Rapp, G. 2009. Archaeomineralogy, Berlin, Heidelberg: Springer-Verlag.

Rehren, Th. 1997. Die Rolle des Kohlenstoffs in der Prähistorischen Metallurgie. Stahl und Eisen, 117, pp. 8792.

Rehren, Th., Leshtakov, P. \& Penkova, P. 2016. Reconstructing Chalcolithic copper smelting at Akladi cheiri, Chernomorets, Bulgaria In: Nikolov, V. \& Schier, W. (eds.) Der Schwarzmeerraum vom Neolithikum bis in die Früheisenzeit (6000-600 v.Chr.). Kulturelle Interferenzen in der zirkumpontischen Zone und Kontakte mit ihren Nachbargebieten. Rahden/Westf.: Verlag Marie Leidorf GmbH.

Renfrew, C. 1969. The autonomy of the south-east European Copper Age. Proceedings of the Prehistoric Society 35, pp. 12-47.

Roberts, B. W., Thornton, C. P. \& Pigott, V. C. 2009. Development of metallurgy in Eurasia. Antiquity, 83, pp. 1012-1022.

Seeliger, T. C., Pernicka, E., Wagner, G. A., Begemann, F., Schmitt-Strecker, S., Eibner, C., Öztunal1, Ö. \& Baranyi, I. 1985. Archäometallurgische Untersuchungen in Nord- und Ostanatolien. Jahrbuch des Römisch- Germanischen Zentralmuseums Mainz, 32, pp. 597-659.

Sperl, G. 1990. Zur Urgeschichte des Bleies. Zeitschrift für Metallkunde, 81, pp. 799-801.

Sperl, G. 1991. Zur Geschichte der Verwendung des Bleies (Die Rolle des Bleies in der Geschichte der Metallurgie). Jahrestagung des Arbeitskreises Archäometrie in der Fachgruppe Analytische Chemie der Gesellschaft Deutscher Chemiker (GDCH) und des Arbeitskreises Archäometrie und Denkmalpflege der Deutschen Mineralogischen Gesellschaft (DGM), 6.-8.3.1991, Berlin. Berlin, pp. 47-51.

Stech, T. 1990. Neolithic Copper Metallurgy in Southwest Asia. Archeomaterials, 4, pp. 55-61.

Strahm, C. 1984. Die Anfänge der Metallurgie in Mitteleuropa. Helvetica Archaeologica, 97, pp. 1-39. 
Thornton, C. P. 2001. The Domestication of Metal: A Reassessment of the Early Use of Copper Minerals and Metal in Anatolia and Southeastern Europe (unpublished MPhil thesis). Cambridge: University of Cambridge.

Thornton, C. P. 2009. The Emergence of complex metallurgy on the Iranian Plateau: escaping the Levantine Paradigm. Journal of World Prehistory, 22, pp. 301-327.

Thornton, C. P. 2014. The Emergence of Complex Metallurgy on the Iranian Plateau. In: Roberts, B. W. \& Thornton, C. P. (eds.) Archaeometallurgy in Global Perspective. New York: Springer, pp. 665-696.

Twiss, K. C., Bogaard, A., Bogdan, D., Carter, T., Charles, M. P., Farid, S., Russell, N., Stevanović, M., Yalman, E. N. \& Yeomans, L. 2008. Arson or Accident? The Burning of a Neolithic House at Çatalhöyük. Journal of Field Archaeology, 31, pp. 41-57.

Tylecote, R. F. 1976. A History of Metallurgy, London: The Metals Society.

Wagner, G. A., Begemann, F., Eibner, C., Lutz, J., Öztunali, Ö., Pernicka, E. \& Schmitt-Strecker, S. 1989. Archäometallurgische Untersuchungen an Rohstoffquellen des frühen Kupfers in Ostanatoliens. Jahrbuch des Römisch- Germanischen Zentralmuseums Mainz, 36.

Wagner, G. A., Pernicka, E., Seeliger, T. C., Lorenz, I. B., Begemann, F., Schmitt-Strecker, S., Eibner, C. \& Öztunali, Ö. 1986. Geochemische und isotopische Charakteristika früher Rohstoffquellen für Kupfer, Blei, Silber und Gold in der Türkei. Jahrbuch des Römisch- Germanischen Zentralmuseums Mainz, 33, pp. 723-730.

Wertime, T. A. 1964. Man's first encounters with metallurgy. Science, 146, pp. 1257-1267.

Yalçın, Ü. \& Pernicka, E. 1999. Frühneolitische Metallurgie von Aşıklı Höyük. In: Hauptmann, A., Pernicka, E., Rehren, Th. \& Yalçın, Ü. (eds.) The Beginnings of Metallurgy, Der Anschnitt, Beiheft 9. Bochum: Deutsches Bergbau-Museum, pp. 45-54.

Yener, K. A., Sayre, E. V., Joel, E. C., Özbal, H., Barnes, I. L. \& Brill, R. H. 1991. Stable lead isotope studies of central taurus ore sources and related artifacts from eastern mediterranean chalcolithic and bronze age sites. Journal of Archaeological Science, 18, pp. 541-577. 